\title{
A proposed Global Boundary Stratotype Section and Point for the base of the Middle Ordovician Series: The Niquivil section, Precordillera of San Juan, Argentina
}

\author{
1 CONICET - Facultad de Ciencias Exactas, Físicas y Naturales, Universidad Nacional de Córdoba, Casilla de Correo 1598, 5000 Córdoba, \\ Argentina.E-mail: galbanesi@arnet.com.ar; mcarrera@com.uncor.edu \\ 2 CONICET - Departamento de Geología, Universidad Nacional de Río Cuarto, Ruta Nacional 36 km 601, 5800 Río Cuarto, Argentina. \\ E-mail:fcanas@exa.unrc.edu.ar \\ 3 Department of Geological Sciences, The Ohio State University, Columbus, OH 43210, USA. E-mail: saltzman.11@osu.edu
}

The Niquivil section, Argentine Precordillera, fulfills most of the requirements for a Global Stratotype Section and Point (GSSP) for the base of the Middle Ordovician Series. It has excellent conodont biostratigraphy in a continuous succession of uniform lithology, is readily accessible, and the critical interval is not tectonically affected. The position of the Lower/Middle Ordovician Series boundary in the Central Precordillera is placed at the middle part of the San Juan Formation, an open-platform carbonate unit. The Niquivil section is proposed as a GSSP for the base of the Middle Ordovician, which is marked by the FAD of the conodont Cooperignathus aranda (Cooper). It occurs in level NCA, at the upper part of the Oepikodus evae Zone (overlapping uppermost records of $\mathrm{O}$. evae in association with other guide species); i.e., $100.15 \mathrm{~m}$ above the base of the reference section. The auxiliary Peña Sombría section from northern Precordillera records graptolites of the lower (but not lowest) Middle Ordovician in the Isograptus victoriae maximus Zone, few meters above the proposed boundary biohorizon. The range of $\mathrm{C}$. aranda can be correlated with the I. victoriae lunatus Zone up to the lower part of the Undulograptus austrodentatus Zone in diverse sections of the world. C. aranda presents cosmopolitan distribution and occurs in virtually all environments. The proposed GSSP preserves a carbon-isotope record that provides an auxiliary marker of potential global application. Radiometric dating of $K$-bentonite samples, interbedded with carbonate strata yielding lower records of $\mathrm{C}$. aranda, were recovered from the auxiliary Talacasto section in Central Precordillera (469.8 \pm 2.3 $M a, U-P b$ SHRIMP dating).

\section{Introduction}

\section{Background and motivation}

Since the International Subcommission on Ordovician Stratigraphy (ISOS) adopted the first appearance datum (FAD) of the conodont Tripodus laevis to mark the base of the Middle Ordovician Series (Webby, 1998), diverse problems arose upon the selection of this biostratigraphic marker. The Whiterock Narrows Section at Monitor Range, Nevada, proposed by Finney and Ethington $(2000 \mathrm{a}, \mathrm{b})$ as GSSP has been found to be of questionable usefulness in several respects. Detailed analyses of problems concerning both the selected conodont key species and the proposed section were posted on the "Ordovician Stratigraphy Discussion Group" internet site: $h t t p: / /$ seis.natsci.csulb.edu/ordstrat1.

The position of the Lower/Middle Ordovician Series boundary in the Argentine Precordillera was recently determined by means of conodont biostratigraphy to be the FAD of Tripodus laevis s.l. in the middle part of the San Juan Formation, Yanso Section, Potrerillo Mountain (Albanesi et al., 1998a) (Figure 1). In search of this horizon in graptolite facies, Ortega and Albanesi (1999) and Albanesi and Ortega (2000) investigated new sections in northern Precordillera, which resulted in the recognition of the lower (but not lowest) Middle Ordovician zones based on the Isograptus complex (beginning with I. victoriae maximus Zone), which is coeval to the T. laevis Zone (Albanesi et al., 1999). Graptolite biohorizons that lie within the critical interval we are considering were still not found in the Precordillera. After examination of diverse alternatives, Albanesi and Carrera (2001, and referred internet address) proposed the Niquivil Section of Central Precordillera as GSSP for the base of the Middle Ordovician by the FAD of the conodonts Cooperignathus aranda (Cooper) and Texania heligma Pohler. This particular level was selected for being located just in the uppermost part the widely recognized Oepikodus evae Zone (referred taxa are considered key substitutes after the absence of $T$. laevis sensu stricto in the Precordillera).

On this basis, we maintain our proposal on the biohorizon as published and discussed in the business meeting of the SOS at the GSA annual meeting held in Boston (Albanesi and Carrera, 2001) posted in the internet site of the "Ordovician Stratigraphy Discussion Group", where there were posted several papers regarding this issue. Most recently, Albanesi et al. (2003) presented a contribution to the 9th ISOS held in Argentina, with a formal proposal of the Niquivil Section as GSSP for the Lower/Middle Ordovician boundary, that 

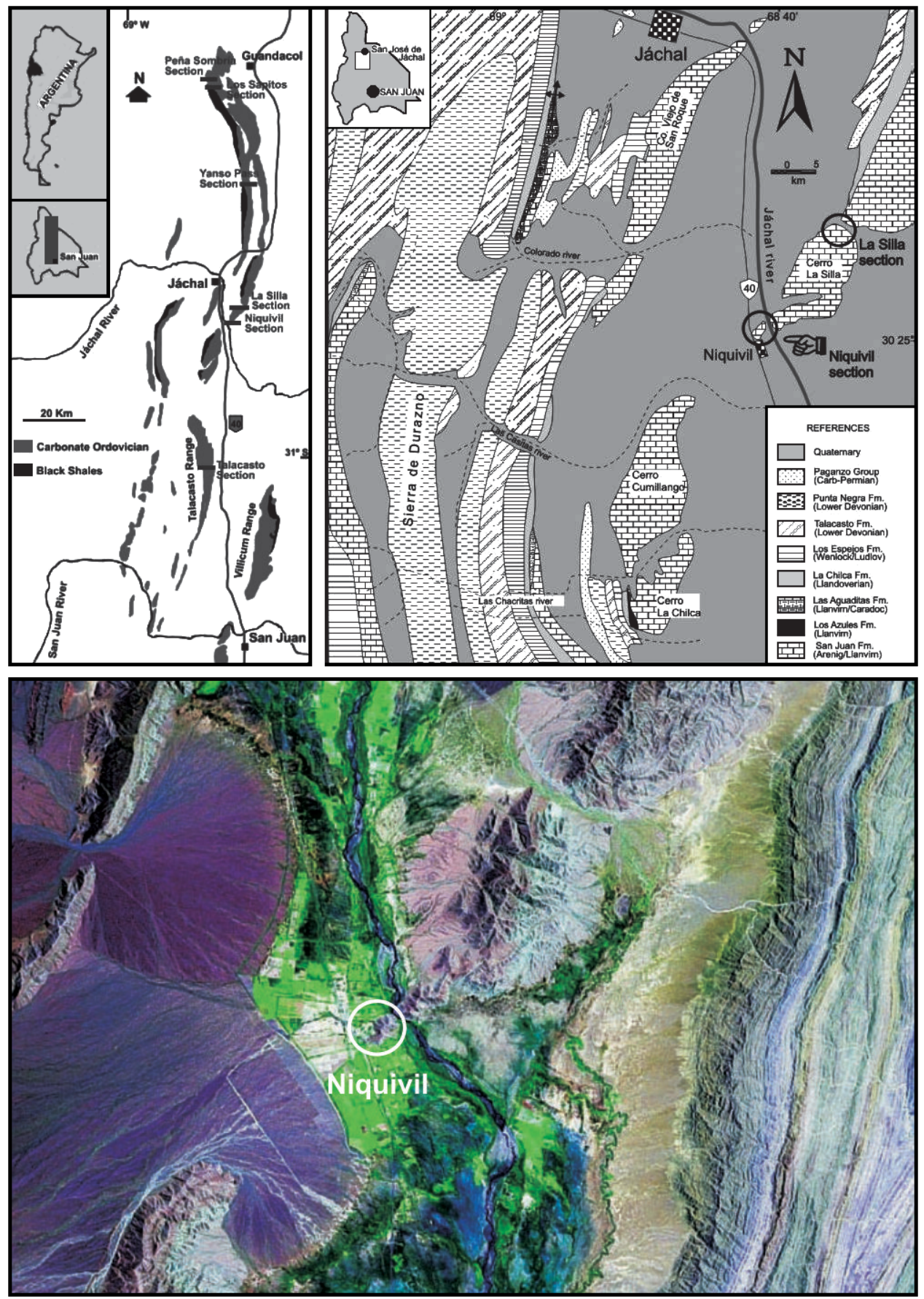

Figure 1 Location map of Ordovician carbonate outcrops in the Argentine Precordillera. The positions of the Niquivil and auxiliary sections are indicated. Schematic geological map of the central Precordillera with the study area, and the location of the Niquivil and La Silla sections. Satellite image of the central Precordillera of San Juan Province, Argentina, and the position of the Niquivil locality.

precludes other kind of dramatic biostratigraphical changes in the eventual selection of the stratotype of this global series and stage boundary (cf., Mitchell, 2001, in: "Ordovician Stratigraphy Discussion Group" internet site)

Present report is addressed to provide a thorough description of the Niquivil section (Figures 1,2,4), and evaluation of the global correlation potential for the proposed biohorizon.

\section{Geological setting}

The lower Paleozoic strata in the Argentine Precordillera consist of a thick Paleozoic sedimentary succession, where CambroOrdovician rocks show transitions from nearshore carbonate bank through mixed carbonate-siliciclastic slope deposits to basinal clastics. A $2500 \mathrm{~m}$ thick sequence of limestones constitutes the base of a lower Paleozoic marine sequence.

The Lower/Middle Ordovician boundary interval occurs within the San Juan Formation, which is a muddy fossiliferous carbonate open platform on top of a Cambrian to Lower Ordovician carbonate platform succession (Cañas, 1999). The development of reef-mounds and open fully marine conditions in the upper Tremadocian (Cañas and Carrera, 1993; Keller et al., 1994) represents an important change in the basin evolution. After this major transgressive event, subtidal lithotopes prevailed during deposition of the San Juan Formation (Cañas, 1995, 1999).

Earliest conodonts recorded from the formation demonstrate that the lower levels still belong to the uppermost Tremadocian (Paltodus deltifer Zone, Keller et al., 1994; Albanesi et al., 1998a). The upper boundary is drawn within the Darriwilian, with the last occurrence of gray, often nodular wackestones and packstones containing the characteristic platform fauna. These upper beds are overlain by an alternation of black shales and platy mudstones, in other places only by graptolitic black shales. The diachronic top of the San Juan Formation was dated at several localities. In the northern sections (Gualcamayo and Guandacol rivers area), conodonts and graptolites indicate an early Middle Ordovician age (Castlemainian 3, Isograptus victoriae maximus) for the transitional beds between the San Juan Formation and the black shales of the Gualcamayo Formation (Ortega, et al., 1985; Ortega and Albanesi, 1999); whereas elsewhere conodonts have proven an early Darriwilian (Lenodus variabilis - Eoplacognathus suecicus zones) age for the top of the limestones (Hünicken and Ortega, 1987; Lehnert, 1995a,b; Albanesi et al., 1998a,b; Ortega and Albanesi, 2000).

\section{Sequence stratigraphy}

Ordovician deposits from the Precordillera basin are related to the development of five to six depositional sequences (Astini, 1993; Keller et al., 1998; Cañas, 1999). In the uppermost Tremadocian (upper Paltodus deltifer - Paroistodus proteus zones), the development of widespread muddy fossiliferous carbonates associated with spongemicrobial reef-mounds (Carrera, 1991; Cañas and Carrera, 1993) represent the onset of a major transgressive event, the beginning of the San Juan (SJ) sequence (Cañas, 1995, 1999) (Figures 4, 10). Subtidal lithotopes and open marine biotic associations prevailed during deposition of the San Juan Formation. Communities are dominated by brachiopods and sponges while echinoderms and gastropods are also abundant components. In the basal part of the formation, at the beginning of the transgressive event, microbial-sponge reef mounds developed in an inner ramp setting. Microbial communities with the 

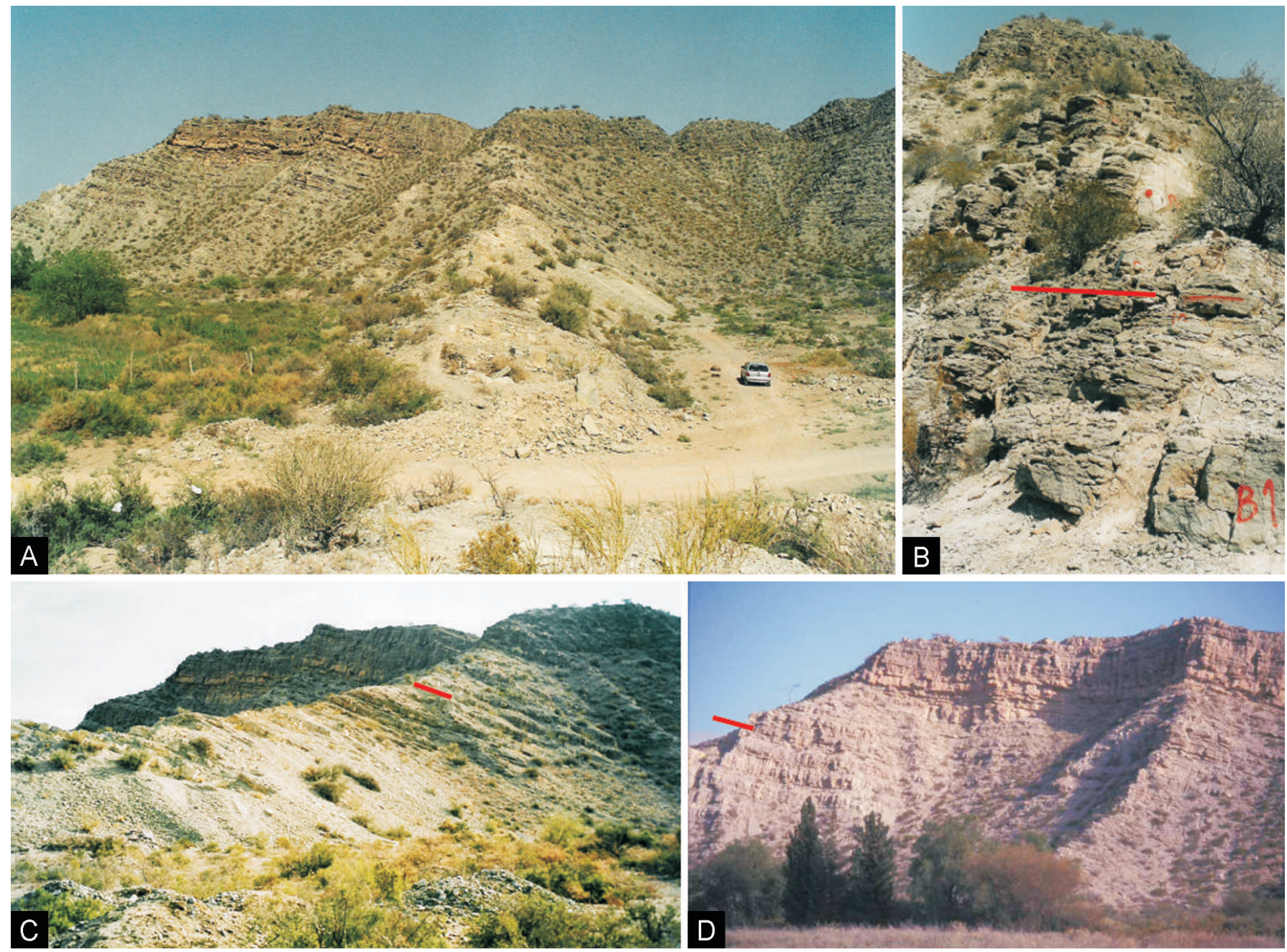

Figure 2 A, Panoramic view of the Niquivil section (see the road just parallel to the measured section). B, Close up view of the critical Lower/Middle Ordovician boundary interval (the red line indicates the boundary position). C, Lateral view of the measured section. $D$. Frontal view of the studied section (see the prominent reefal stratification in the upper part of the section). All views to the $N$.
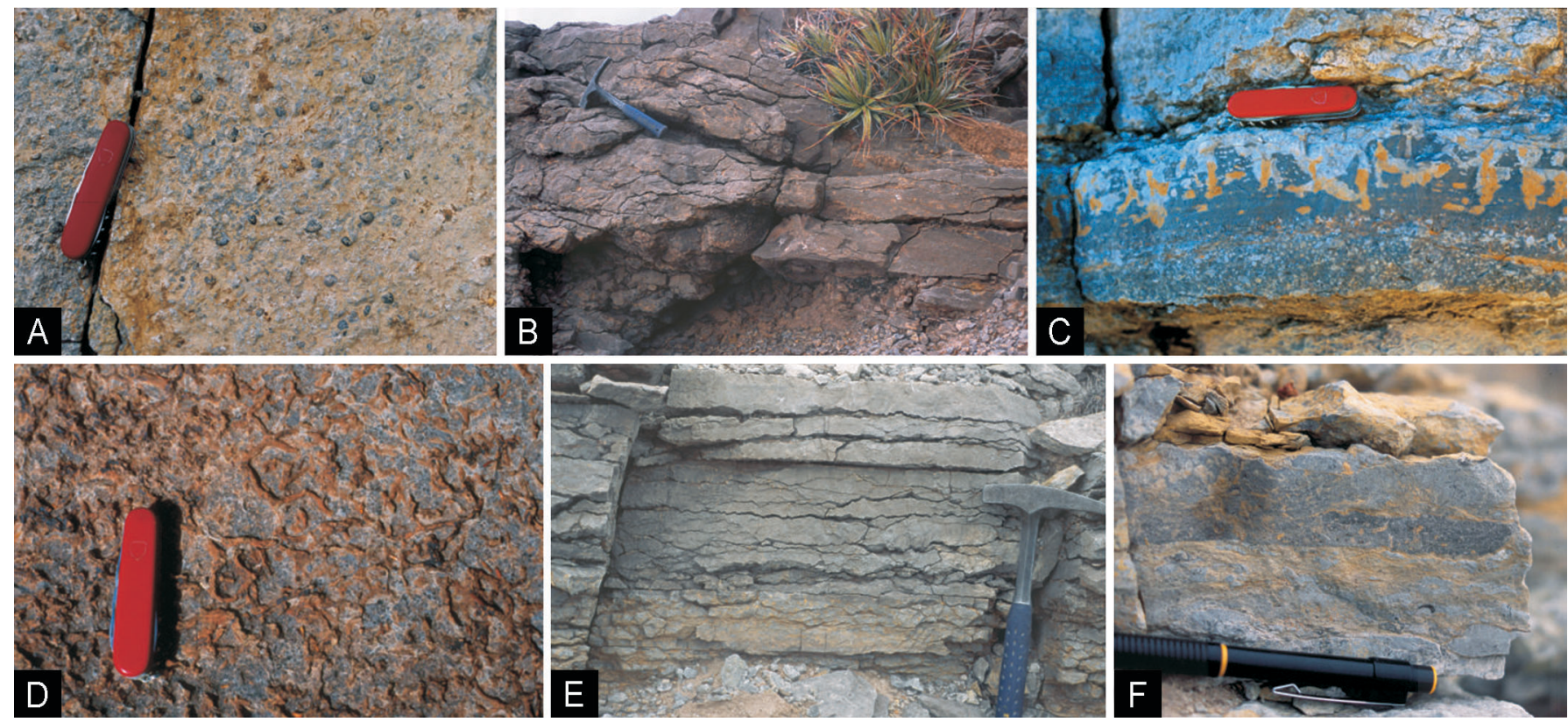

Figure 3 Lithology of the Niquivil section. A, Shell bed in skeletal wackestone, litho-skeletal facies association. B, Shoal and reefs facies association. C, Storm bed, litho-skeletal facies association. D, Thalassinoides in skeletal limestone. E, Litho-skeletal facies association (wackestones and thin interbedded grainstones, the Lower/Middle Ordovician boundary horizon, out of the frame, occurs within this lithology). F, Skeletal wackestone, litho-skeletal facies association. 


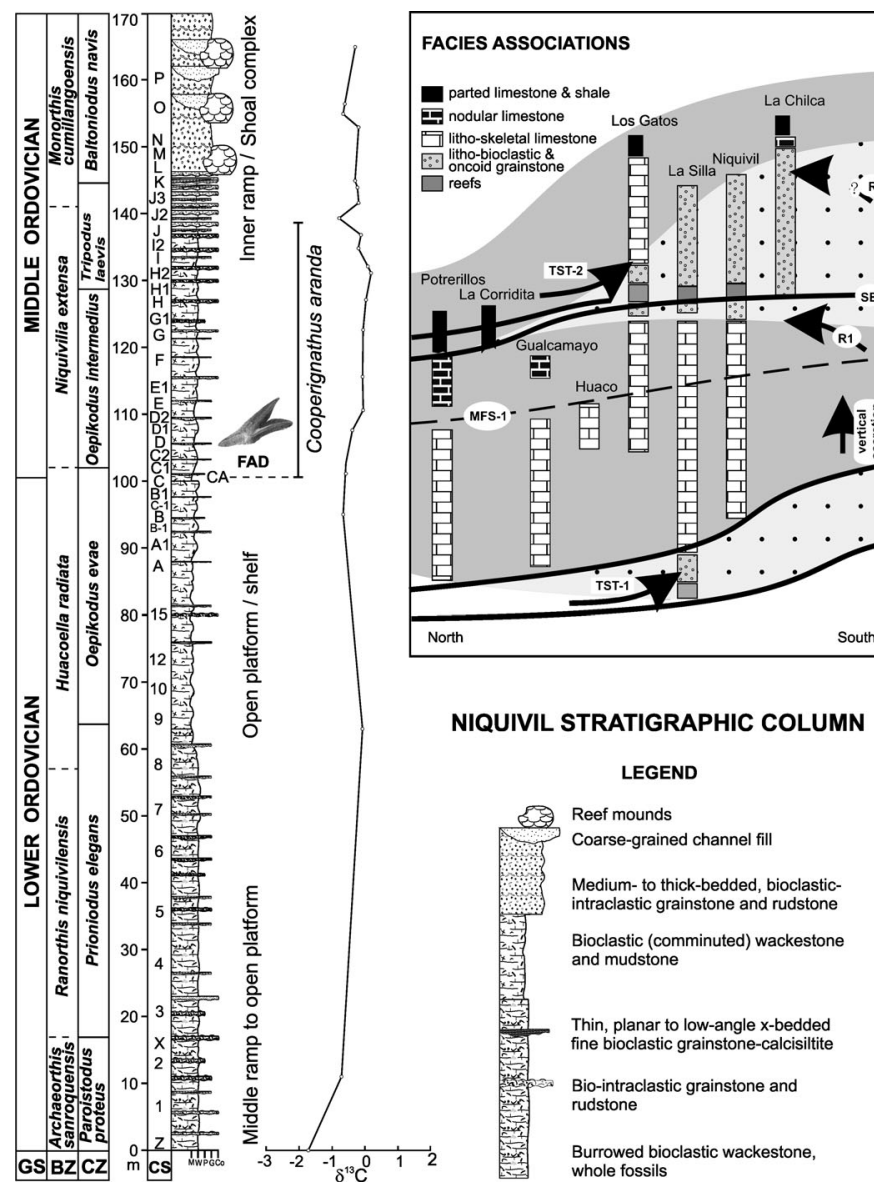

Figure 4 Stratigraphic column of the Niquivil section with the Carbon Isotope curve (abbr.: GS, global series; BZ, brachiopod zones; CZ, conodont Zones; CS, conodont samples). Diagram showing the carbonate facies associations of the San Juan Formation through classic localities of the Precordillera.

conspicuous occurrence of the calcareous cyanobacteria Girvanella constitutes the primary framework of these bioherms. Lithistid demosponges and the receptaculitid Calathium are accessory framebuilders.

Skeletal wakestones and packstones intercalated by stormrelated intraclastic grainstones are the most conspicuous lithologies in a major interval of the San Juan Formation. Middle ramp deposits accreted in the transgressive sequence. The maximum flooding surface occurs at the middle part of the formation in the Oepikodus evae Zone. Condensed skeletal concentrations and encrusting organisms associated with hard substrates appeared in this interval. Storm deposits are less abundant but their frequency indicates a middle ramp setting. The proposed boundary level in the Niquivil section lays well above this point, and thus into what are interpreted as high-stand deposits (O. evae -O. intermedius zones). This point is considered important, for no significant sedimentary breaks are expected to occur between the maximum flooding surface and the following sequence boundary (top of Tripodus laevis s.l. Zone).

Above the critical boundary interval, in the Baltoniodus navis Zone, fossiliferous wackestones and grainstones of the SJ sequence are capped by stromatoporoid patch reefs and stromatoporoid-lithistid-algal reef-mounds (Cañas and Keller, 1993; Keller and Flügel, 1996). This facies represents the onset of the SJ-G sequence (Cañas, 1999). The second reef-mound horizon appears after a regressive stage in the next transgressive sequence. The addition of stromatoporoidlike organisms among framebuilders is an important feature of the upper reef-mounds. Carbonate sedimentation culminates in the Darriwilian (Lenodus variabilis - Eoplacognathus suecicus zones) with nodular wackestones and packstones containing diverse open platform faunas. Paleoecological and sedimentological analyses of these faunas suggest a regional slope to the north (Cañas, 1995, 1999; Sánchez et al., 1996).

\section{Lithology and facies of the San Juan Formation}

The San Juan Limestone exhibits a wide range of carbonate textures, most of them bioclastic and/or skeletal (whole fossils), with variable amounts of lime mud, and variably dolomitized. Marked pseudobedding distinguishes these rocks showing alternating gray, massive horizons, and wavy to unevenly bedded levels that weather out as rubble, with a yellowish to tan cast where dolomite and argillaceous material concentrates in solution seams and compacted burrows (Figures 3, 4). Lithologies of the San Juan Formation were described in detail by Cañas $(1995,1999)$ and Keller (1999). Cañas (1999) grouped lithofacies present in the unit in five associations, all representing fully-marine, open platform deposits.

The boundary interval falls within high-stand deposits that follow a thick transgressive unit making up the base of the San Juan Formation, and are characterized by a skeletal and lithoclastic facies association (Cañas, 1999). Facies of this association include burrowed bioclastic wackestone, skeletal (whole fossils) wackestone, and interbedded thin to medium bedded lithoclastic-bioclastic grainstone, packstone and thin-intraclastic rudstone beds. Burrowed bioclastic and whole fossil wackestone are the prevailing lithologies (Figure 3). Carbonate mud is ubiquitous within this facies (60-95\%). Skeletal fragments and whole fossils represent a diverse fauna which included brachiopods, trilobites, pelmatozoans, gastropods, ostracods, nautiloids, lithistid sponges, receptaculitids, bryozoans, conodonts, the probable green algae Nuia (that is particularly abundant within this facies), and the probable cyanobacterium Girvanella, that occurs as enrolled nodules, encrusting micro-framestones, surficial cortoids, or as dispersed threads (see Pratt, 2001). Fine comminuted bioclastic wackestone to mudstone also are included in this facies association. Whole fossils are scarce in this facies, and trilobite fragments are more frequent than brachiopods. Nuia occurs less frequently, whereas the probable cyanobacterium Halysis shows the reverse trend. All these facies exhibit pervasive bioturbation,

Interbedded with the above described facies are frequent centimeter to decimeter thick, lithoclastic-bioclastic grainstone and rudstone beds. They usually have sharp, irregular erosive bases developed on top of underlying wackestones. The coarser grained beds are composed mostly of $\mathrm{mm}$ - to $\mathrm{cm}$ - sized intraclasts and bioclasts derived mostly from the underlying beds, are poorly sorted and exhibit crude grading. Finer grained varieties are composed of bioclasts and peloids, are usually well-sorted and may present lowangle cross lamination. Both lithofacies have been observed to grade vertically and laterally in short distance (a few meters), and both grade into the dominant wackestone types.

The facies types recognized in this interval are rather uniform, indicating continuous subtidal conditions. A diverse marine fauna and ubiquitous burrowing, along with the lack of structures indicative of shallow-water traction processes or of subaerial exposure, suggest a low energy, open-platform environment, located within the photic zone as indicated by calcareous algae and cyanobacterium. Periods of reduced sedimentation rates are indicated by the presence of reworked intraclasts indicating incipient hardground formation, and cyanobacterial (Girvanella) crusts formed onto the substrate. The interbedded bioclastic-lithoclastic grainstone and rudstones are interpreted as storm deposits (cf., Kreisa, 1981; Markello and Read, 1981; Dattilo, 1993). The paucity of storm events near the proposed boundary level in relation to other parts of the section suggests a rather distal position on the shelf (cf., Aigner, 1985).

\section{Depositional environments}

The San Juan Formation was deposited on top of an open (unrimmed) carbonate shelf, bounded to the west by continental slope and oceanic basin deposits. Despite this long recognized relationship, no significant changes in facies associations are recorded in this direction in the shallow platform carbonates. Although micro- 
bial-sponge reef mounds and stromatoporoid patch reefs, as well as thick oncoid grainstones are restricted to the eastern sections, no facies association formed below the SWB was recorded at the westernmost sections. This indicates that, on palinspastic restoration, inclination in that direction was negligible.

At least from the earliest Middle Ordovician onwards, a homoclinal ramp was developed in association with a local depocenter in the northern Guandacol area. The inner ramp was defined by the FWB, a high energy zone where Girvanella-oncoids banks, lime sand shoals and small bioherms were formed. Remarkably, similar facies associations were developed in coeval (Isograptus victoriae Zone) open platform settings of western North America as part of regressive oncoid-shoal systems, which included lithistid spongesCalathium bioherms.

Skeletal-lithoclastic limestones aggraded over most of the open platform and middle ramp environments (Lower/Middle Ordovician boundary interval), which was a low-energy setting periodically affected by storms, whereas the outer ramp was the site of accumulation of nodular wackestones and mudstones, probably as periplatform hemipelagic muds derived from the shallower platform, together with autochthonous skeletal material. This association occurs onto the platform as outer-shelf deposits before complete drowning in the Darriwilian.

Rocks of the San Juan Formation may be considered as part of the sponge/algal facies, which was widespread around the North American continental edge during the Early Ordovician (Alberstadt and Repetski, 1989). This regional facies is characterized by wackestones and mudstones with a distinct biotic assemblage formed by sponges (especially Archaeoscyphia), Calathium, Nuia, Girvanella, and Sphaerocodium. These rocks hosted small reef-mounds (Church, 1974; Toomey and Nitecki, 1979) that are almost identical to those of the San Juan Formation, and were interpreted to have been deposited in a normal, open marine environment, away from the more restricted shallow shelf settings of the continental interior (Alberstadt and Repetski, 1989).

\section{The Niquivil section}

\section{Location and stratigraphy}

The Niquivil section is located in the La Silla range, easternmost part of the eastern tectofacies, geographical coordinates: $30^{\circ} 25^{\prime} \mathrm{S}, 68^{\circ}$ $40^{\prime}$ W, altitude: ca. 1000 masl (Figure 1). It is situated in the Niquivil village along the National road 40, $22 \mathrm{~km}$ south of San José de Jáchal town. The study area is a non private land that could be declared as protected area for future studies and preservation (Figure 2).

The exposed outcrops of the San Juan Formation are represented by a thick (ca. $200 \mathrm{~m})$, east-dipping ( $50^{\circ}$ strike, $20^{\circ} \mathrm{NE}$ dip) succession of carbonate rocks (Figures 2,4). Outcrops in the section correspond to the lower and middle intervals of the San Juan Formation. The lower interval (Paroistodus proteus and Prioniodus elegans zones - Archaeorthis sanroquensis and Ranorthis niquivilensis zones) is represented by approximately 50 meters of skeletal wakestones including conspicuous levels of shell beds (mainly brachiopods and gastropods) and alternating intraclastic grainstones in lenses or discontinuous geometries (storm beds).

The middle interval of the San Juan Formation in the Niquivil section corresponds to the Oepikodus evae Zone (ca. $40 \mathrm{~m}$ ), which is partly equivalent to the Huacoella radiata Zone. Here, the thickness of the skeletal wakestones increases and the grainstones levels occurs sporadically. Thin glauconitic levels and firmgrounds occur in this interval. Laminar and encrusting organisms such as sponges, bryozoans, receptaculitids and echinoderms are common dwellers of these substrates. This interval is related to the maximum flooding surface matching the Oepikodus evae transgression.

In the upper part of the Oepikodus evae Zone and in the $O$. intermedius Zone (ca. $45 \mathrm{~m}$ ), the glauconitic levels disappeared and the grainstones became more common. In terms of the local brachiopod biostratigraphy, the proposed Lower/Middle Ordovician bound- ary interval occurs approximately across the limit of the Huacoella and Niquivilia zones (conodont biostratigraphy is discussed in detail below). No apparent environmental change occurs in this boundary at sedimentological resolution. An important facies change is recorded in the upper limit of the Niquivilia Zone and the beginning of the Monorthis Zone. Fifty meters of Pelmatozoan-rich grainstones and rudstones shoals, including stromatoporoid-like organisms and small patch reefs occur at the base of the Monorthis Zone marking the sequence boundary after a sea level drop.

Quaternary sediments cover the sequence, but it is precisely correlated with the nearby La Silla and Cerro Viejo sections. Both localities include the lower part of the formation (P. proteus conodont Zone). The Cerro Viejo section includes the complete upper part of the Formation (Lenodus variabilis conodont Zone, Ahtiella brachiopod Zone) and the overlying Los Azules Formation.

\section{Biostratigraphy of brachiopods and trilobites}

Herrera and Benedetto (1991) and Benedetto $(1998,2002)$ recognized six brachiopod zones in the San Juan Formation. The lower interval of the formation corresponds to the Archaeorthis sanroquensis Zone that includes the Paroistodus proteus and Prioniodus elegans conodont zones and the Ranorthis niquivilensis Zone (Figure 5).

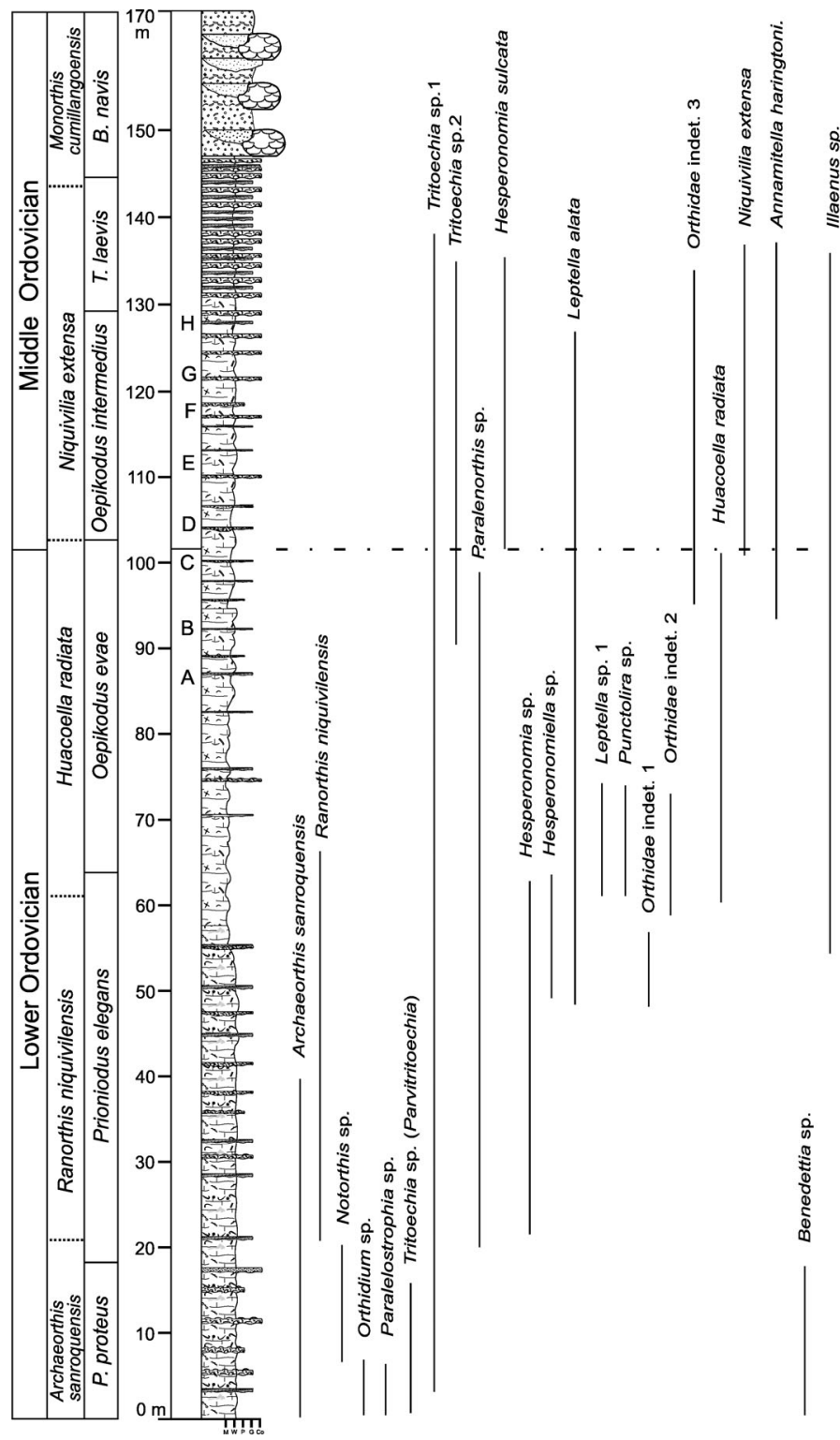

Figure 5 Vertical distribution of brachiopods and trilobites in the Niquivil profile. 
The middle part of the San Juan Formation includes the Huacoella radiata Zone approximately coincident with the Oepikodus evae Zone. The Niquivilia extensa Zone is equivalent to the $O$. intermedius Zone and lower Tripodus laevis Zone. The Monorthis cumillangoensis Zone corresponds to the upper Tripodus laevis, Baltoniodus navis, and Microzarkodina parva zones. The upper part of the formation corresponds to the Ahtiella argentina Zone that includes the Lenodus variabilis, and the lower part of the Eoplacognathus suecicus zones in numerous sections.

Vaccari $(1993,1995,2001,2003)$ recorded several associations of trilobites in the San Juan Formation. In the lower part of the unit (upper stage of the Lower Ordovician), the L. (Leiostegium) precordilleranus Zone occurs, including Leistegium, Peltabelia, Uromystrum, and Benedettia. In the Annamitella harringtoni Zone (straddling the Lower/Middle Ordovician boundary), Annamitella, Illaenus, and Ampyx are the most abundant genera.

The Annamitella tellecheai Zone corresponds to the lower Middle Ordovician and includes genera of both the carbonate ramp (San Juan Formation) and the diachronous distal ramp (Lower Member Gualcamayo Formation). Most of the genera are recorded in these mixed limestone and shale deposits included in the Nileid biofacies (Baldis, 1979; Benedetto et al., 1986)

The Annamitella forteyi Zone (Darriwilian) in the upper part of the San Juan limestones includes the genera Waisfeldaspis, Basilicus, Scotoharpes, Mendolaspis, and Pliomerops. Vaccari (1995) referred this association to the Illaenid-Cheirurid biofacies of Fortey (1975).

\section{The conodont record}

The first conodont biostratigraphy of the Niquivil section was published by Lehnert (1993), who defined six assemblage zones. The present study presents a refined biostratigraphy for the referred critical interval, and follows the scheme established by Albanesi et al. (1998a) for the Argentine Precordillera (see revision by Albanesi and Ortega, 2002, for regional correlation). It is based on 43 productive carbonate conodont samples, $3 \mathrm{~kg}$ each on average, which total over $131 \mathrm{~kg}$. All samples were completely digested by conventional acid etching techniques ( $10 \%$ acetic acid) and yielded 7450 wellpreserved conodonts, which represent 56 multielement species (Figure 6). All of the 56 conodont species were previously described and illustrated; in particular, for taxonomic documentation on conodonts from the San Juan Formation, the reader is referred to the comprehensive studies published by Serpagli (1974), Lehnert (1995a), and Albanesi (1998a). Samples were taken throughout a measured $170 \mathrm{~m}$ thick stratigraphic section (productive samples cover ca. $150 \mathrm{~m}$ ), with 0.5 to $0.15 \mathrm{~m}$ sampling intervals, to the limit of stratigraphic resolution within the critical boundary interval. Samples from the critical interval (mostly wackestones) produced about 200 elements per $\mathrm{kg}$, on average. Grainstones or coarser rocks from the patch reefs-shoals interval at the top of the section produced less than 5 specimens per $\mathrm{kg}$. Conodont elements show a Conodont Alteration Index of
1.5-2 (Epstein et al., 1977), demonstrating low overburden paleotemperatures that allow for particular geochemical and paleomagnetic studies.

From base to top the Niquivil section comprises the Paroistodus proteus, Prioniodus elegans, Oepikodus evae, Oepikodus intermedius, Tripodus laevis s.1., and Baltoniodus navis interval zones, as defined by Albanesi et al. (1998a) for the Yanso section, Cerro

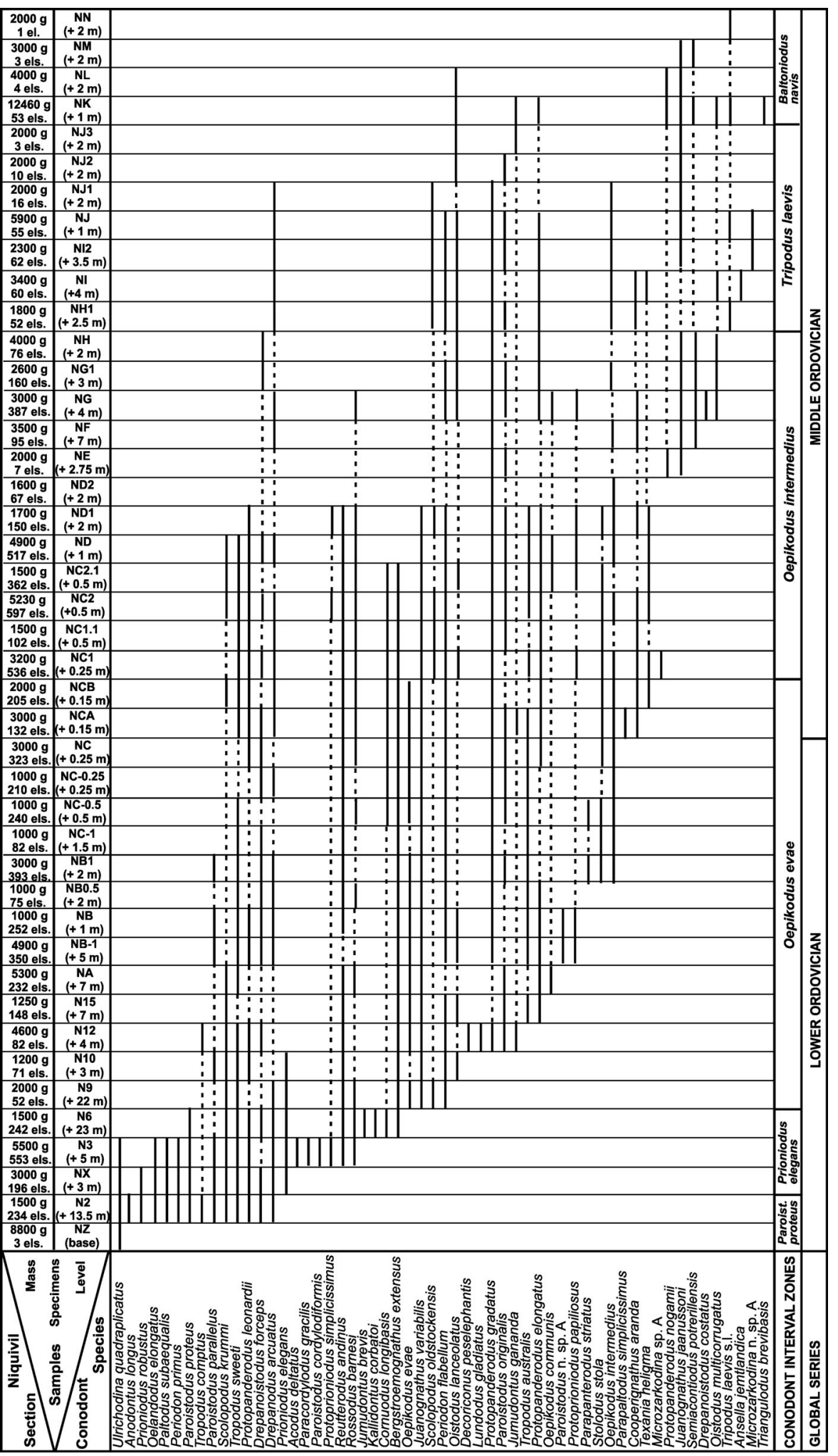

Figure 6 Conodont samples and total number of recovered elements, conodont species ranges (presence-absence distribution), and biozones of the Niquivil section (only productive samples are registered). 


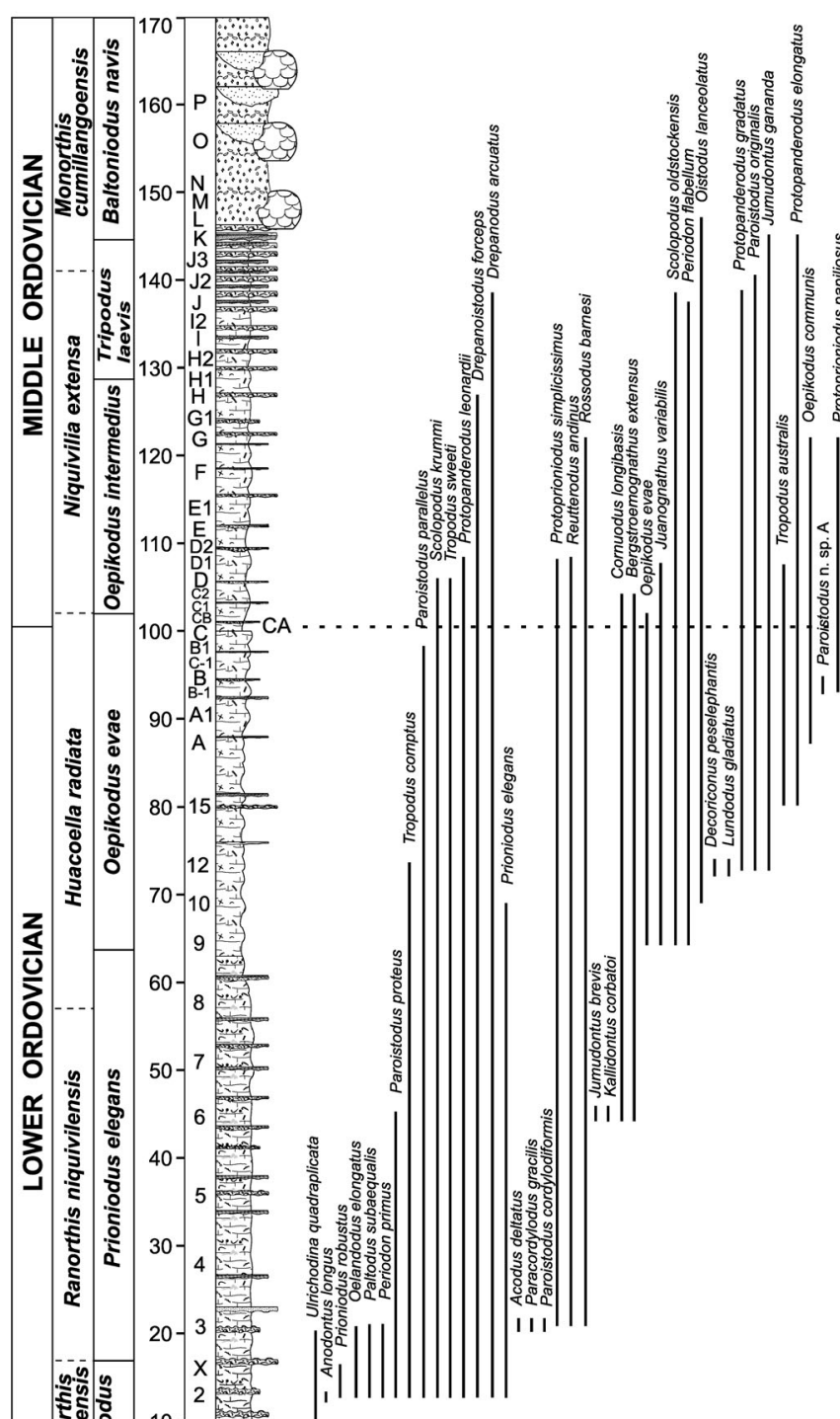

Figure 7 Conodont species ranges in the Niquivil profile, biozones, and the position of the Lower/Middle Ordovician boundary.

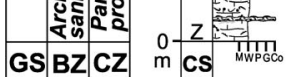

Potrerillo, Central Precordillera. All of these biostratigraphic units are interval zones, whose boundaries are defined by the first appearance datum (FAD) of the eponymous guide conodont species, except for the Oepikodus intermedius Zone. The base of the latter zone is defined by the last appearance datum (LAD) of the key species that characterizes the underlying interval (i.e., Oepikodus evae), and the top of the unit coincides with the base of the overlying zone, which is defined by the FAD of Tripodus laevis s.l. In this particular definition, the Oepikodus intermedius Zone is characterized by the presence of the eponymous species without $O$. evae and T. laevis s.l. (a distinctive interval for the San Juan Formation in the Argentine Precordillera). Basal and uppermost strata of the Niquivil section are not considered for detailed conodont records in present report, so that high resolution biostratigraphy for these parts of the column is pending further studies. Regarding the lower boundary of the Baltoniodus navis Zone, in spite of the absence of the eponymous species in the Niquivil section, the zone is represented by the presence of Triangulodus brevibasis (Sergeeva), a singular species that recurrently makes its appearance in the zone, or correlative interval, everywhere.

The FAD of Cooperignathus aranda (Cooper) (following the emended taxonomy by Zhen et al., 2003) is selected as the key biohorizon for the global Lower/Middle Ordovician Series (Figures 68 ). It occurs in sample NCA, at the uppermost part of the Oepikodus evae Zone (overlapping latest records of $O$. evae); i.e., $100.15 \mathrm{~m}$ above the base of the section, or $43.65 \mathrm{~m}$ below the basal level (NK) of the patch reefs-shoal interval that occurs at the top of the section (Figure 7). Among particular attributes as key species, $C$. aranda is a short-range form that presents cosmopolitan distribution, and occurs in virtually all environments; from shallow- to deep-, warm- to cold-water facies. In the Argentine Precordillera, the range of C. aranda is documented from the uppermost part of the Oepikodus evae Zone into the Tripodus laevis Zone. In terms of global graptolite biostratigraphy, following the records of the Cow Head Group, western Newfoundland (Williams and Stevens, 1988), the vertical distribution of $C$. aranda covers from the middle part of the Isograptus victoriae lunatus Zone up to the lower part of the Undulograptus austrodentatus Zone (Johnston and Barnes, 1999). The phylogeny of Cooperignathus aranda has recently been interpreted by Zhen et al.
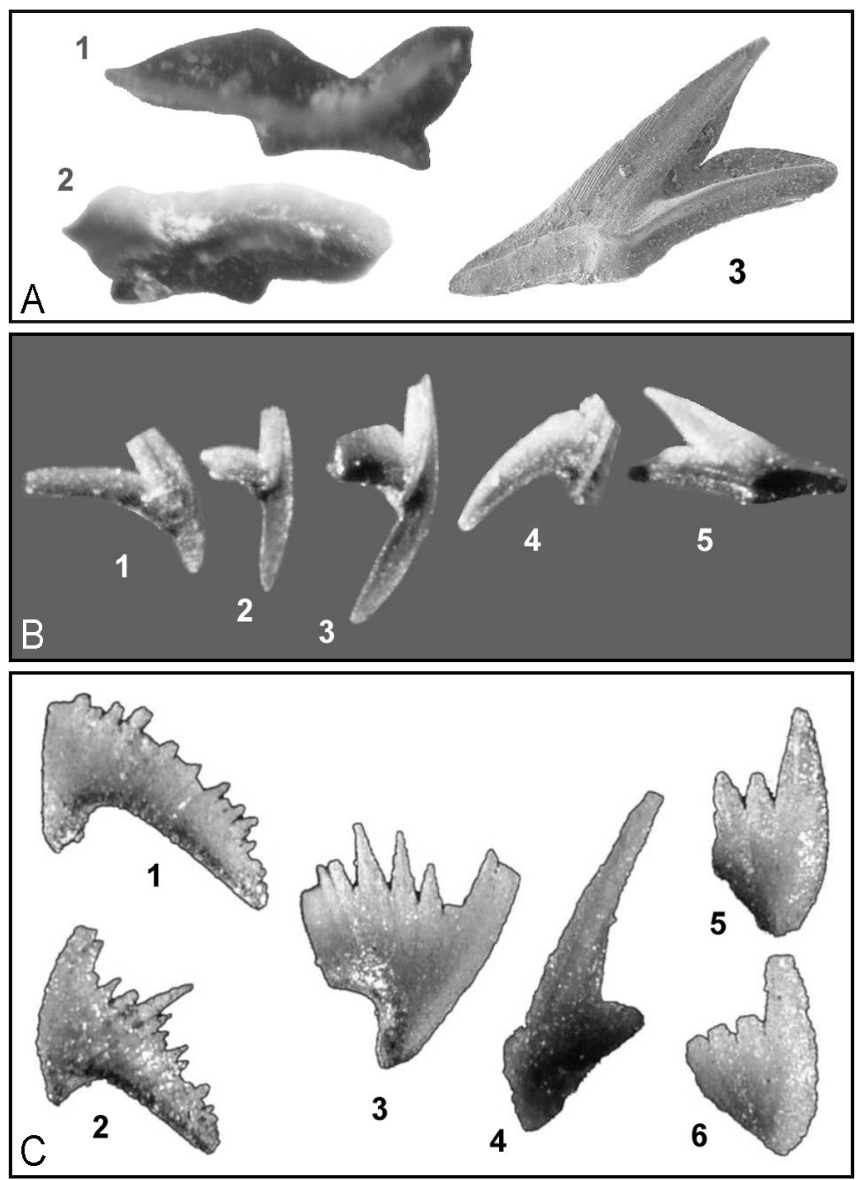

Figure 8 Key conodont species for the proposed GSSP.

A. Cooperignathus aranda (Cooper, 1981), 1) Pa element (upper view), Talacasto section, sample T10, X50;2) same Pa element (lower-lateral view); 3) M element (lateral view), Peña Sombría section, sample PS5, X50.

B. C. aranda, 1-2) Sd?-Sc, Niquivil section, sample $N G, 3) S b$, Niquivil section, sample NCA 4) Sa, Niquivil section, sample ND1, and 5) $M$ element, Niquivil section, sample NCA; all elements lateral view, $\times 25$.

C. Texania heligma (Pohler, 1994), 1-3) S elements, Niquivil section, sample NC1, 4) M element, Niquivil section, sample ND, 5-6) P elements, Niquivil section, sample ND1; all elements lateral view, X50. All pictures are optical microphotographs, except for figure A 2 (SEM). Specimens are deposited in the Museo de Paleontología, Universidad Nacional de Córdoba, Argentina, under the repository code CORD-MP (G. L. Albanesi collection). 
(2003), with the recognition of its ancestral form Cooperignathus nyinti (Cooper, 1981). It is interesting to consider that the FAD of $P$. aranda is composing the array to which the line of correlation has been fit for the graphic correlation of the upper part of the Ibex-area composite section, Millard County, Nevada (Sweet and Tolbert, 1997), verifying a synchronous first appearance of the species for the analysed sections. The paleobiogeographical distribution of $C$. aranda includes several wide regions in both, the shallow-warm and deep-cold-water realms, i.e.:

- North America: e.g., Sweet et al., 1971 (New genus A, partim); Ethington and Clark, 1981 (partim); Tipnis et al., 1978 (New genus A, partim); Repetski, 1982 (New genus A, partim); Alberstadt and Repetski, 1989; Ross et al., 1991, 1997; Repetski et al., 1995; Finney and Ethington, 1992, 2000a; Pyle and Barnes, 2002 (partim).

- Newfoundland: e.g., Fåhraeus and Roy, 1993; Pohler, 1994; Ji and Barnes, 1994 (Protoprioniodus simplicissimus, partim); Johnston and Barnes, 1999, 2000.

- Australia: e.g., Cooper, 1981; Stait and Druce, 1993; Zhen et al., 2003 (revised synonymy).

- Baltoscandia: e.g., Löfgren, 1978 (Protoprioniodus cf. simplicissimus, partim), 1993 (Protoprioniodus sp.); Bagnoli and Stouge, 1997.

- Argentina: e.g., Albanesi et al., 1999, 2003.

- China: e.g., An, 1987 (Protoprioniodus costatus, P. aff. simplicissimus, partim); Wang et al., 2003.

Texania heligma Pohler, 1994, is a distinctive conodont species, well represented in diverse environments, whose FAD is at or very close to the FAD of $C$. aranda (Figures 6-8) and can be adopted as alternative biostratigraphic reference. Its stratigraphic range is restricted to two conodont zones (middle $O$. intermedius to lower T. laevis) or one graptolite zone (I. v. lunatus). Currently, it is known from Newfoundland (Pohler, 1994; Johnston and Barnes, 1999, 2000) and Argentina (Lehnert, 1995a, Albanesi, 1998a). The ancestral form of T. heligma is T. teras, following the phylogenetic interepretation of Pohler (1994).

\section{Correlation}

The vertical distribution of Cooperignathus aranda is welldocumented in the Great Basin of North America, where it ranges from the uppermost levels of the Ibexian Series to the lowermost part of the Whiterockian Series. Considering most recent proposals for a candidate GSSP for the base of the Middle Ordovician Series (Finney and Ethington, 2000a,b) in the Whiterock Narrows section, Monitor Range, Nevada, the first records of $C$. aranda and Tripodus laevis lie at proximate levels (though a stratigraphic break within the critical part of the section precludes confident approximations for both FAD; cf., Mitchell, 2001, in: "Ordovician Stratigraphy Discussion Group" website). However, the FAD for these species in the Great Basin can be controlled in deep basin facies at the Red Canyon section (Lower Member of the Vinini Formation) in the Robert Mountains (Finney and Ethington, 1992, 1995). In this section, conodont collections from the lowest beds of the sandstone unit (base of the Tippecanoe sequence) represent the highest Ibexian conodont Zone of Reutterodus andinus, and they include $C$. aranda (Ross et al., 1997). The next sample, with a lowest Whiterockian conodont collection, including T. laevis and C. aranda, occur just below some single occurrences of Isograptus victoriae lunatus. Lowest Middle Ordovician conodont faunas are well documented in other sections of the Great Basin; e.g., in the upper part of the Wah Wah Formation of western Utah, where $C$. aranda marks the Protoprioniodus aranda - Juanognathus jaanussoni Interval of Ethington and Clark (1981) (i.e., middle part of Fauna E of Ethington and Clark, 1971; or upper part of Reutterodus andinus Zone of Ross et al., 1997), with several common species, also present in the Niquivil section (Juanognathus variabilis, Jumudontus ganada, Oepikodus communis, Parapanderodus striatus, Paroistodus parallelus, Protopanderodus gradatus, Reutterodus andinus). Isolated records of $C$. aranda were reported in the Epler Formation of New Jersey that could approximate same interval (Repetski et al., 1995).

In the Cow Head Group, western Newfoundland, C. aranda is a typical species of Bed 11, though it extends up to Bed 14; that is, from the uppermost $O$. evae Zone through the T. laevis Zone (Johnston and Barnes, 1999, 2000). An equivalent interval is covered in the same sections by the Isograptus v. lunatus to Undulograptus austrodentatus zones (Williams and Stevens, 1988). Following Johnston and Barnes (1999) about the conodont-graptolite ties at Saint Paul's Inlet section (sic, p. 33): "The middle of the I.v. lunatus Zone coincides with first appearance of Oepikodus intermedius, Protoprioniodus aranda and Strachanognathus parvus and the last appearances of a number of taxa, including Acodus? gladiatus, Bergstroemognathus cf. B. extensus, Protoprioniodus simplicissimus, Reutterodus andinus, Stolodus? aff. S. stola, and Tropodus sweeti". Maletz et al. (2003), in a critical revision of the Castlemainian graptolite biostratigraphy in western Newfoundland, confirms the presence of the I. v. lunatus Zone below the conspicuous Bed 12 conglomerate in the Cow Head Group, but regarding the Saint Paul's inlet section argues that "the section does not bear useful graptolite faunas directly below Bed 12 and, thus, the correlation of these strata with the I. v. lunatus Biozone by Williams and Stevens (1988) is conjectural". The Upper Member of the Marathon Limestone, west Texas, bears a highest Ibexian conodont association (including Oepikodus evae and Reutterodus andinus) together with I. v. lunatus (Berry, 1963; Izold, 1993; Bergström, 1995), but C. aranda was not recorded from this distal platform facies where the species is a common component elsewhere. C. aranda occurs near the top of the carbonate El Paso Group in neighbouring basins of westernmost Texas and southern New Mexico (reported as New Genus A of the Fauna 1 of Sweet et al., 1971, by Repetski, 1982). These data may suggest that the FAD of $C$. aranda is, in fact, within the I. v. lunatus Zone. Notwithstanding this situation, $C$. aranda apparently occurs with

\begin{tabular}{|c|c|c|c|c|c|c|c|c|c|c|c|c|}
\hline \multirow{2}{*}{ 通 } & \multirow{2}{*}{ 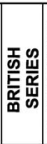 } & \multirow{2}{*}{ 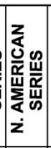 } & \multirow{2}{*}{\multicolumn{2}{|c|}{ 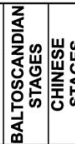 }} & \multirow{2}{*}{ 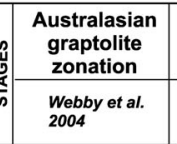 } & \multicolumn{2}{|c|}{$\begin{array}{l}\text { China } \\
\text { Huanghuachang section }\end{array}$} & \begin{tabular}{c|} 
Canada \\
Newfoundland
\end{tabular} & $\begin{array}{c}\text { North America } \\
\text { Great Basin }\end{array}$ & $\begin{array}{c}\text { Baltoscandian } \\
\text { Region }\end{array}$ & $\begin{array}{c}\text { Sweden } \\
\text { Oland }\end{array}$ & $\begin{array}{c}\text { Argentina } \\
\text { Precordillera }\end{array}$ \\
\hline & & & & & & \multicolumn{2}{|c|}{ Wang et al. 2003} & $\begin{array}{l}\text { Johnston and } \\
\text { Barnes } 1999\end{array}$ & $\begin{array}{l}\text { Ethington and } \\
\text { Clark 1981 } \\
\text { Ross et al. } 1997\end{array}$ & \begin{tabular}{|l|} 
Lindstrom 1971 \\
Lofgren 1993 \\
Tolmacheva 2001
\end{tabular} & $\begin{array}{l}\text { Bagnoli and } \\
\text { Stouge } 1997\end{array}$ & $\begin{array}{l}\text { Albanesi et al. } \\
1998,2003\end{array}$ \\
\hline \multirow{4}{*}{ 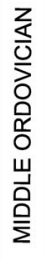 } & \multirow{7}{*}{.0 } & \multirow{3}{*}{ 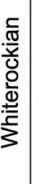 } & \multirow{3}{*}{$\begin{array}{l}\frac{\partial}{2} \\
\frac{\mathbf{s}}{\partial} \\
\end{array}$} & \multirow{3}{*}{ 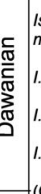 } & \multirow{3}{*}{\begin{tabular}{|l|} 
Isograptus victoriae \\
maximodivergens \\
I. v. maximus \\
I. v. victoriae \\
I. v. lunatus
\end{tabular}} & $\begin{array}{l}\text { Azygograptus } \\
\text { suecicus }\end{array}$ & $\begin{array}{l}\text { Baltoniodus } \\
\text { navis }\end{array}$ & $?$ & $\begin{array}{l}\text { Histiodella } \\
\text { altifrons }\end{array}$ & $\begin{array}{l}\text { Baltoniodus } \\
\text { navis }\end{array}$ & $\begin{array}{l}\text { Baltoniodus } \\
\text { navis }\end{array}$ & $\begin{array}{l}\text { Baltoniodus } \\
\text { navis }\end{array}$ \\
\hline & & & & & & \multirow{3}{*}{$\begin{array}{l}\text { Baltograptus } \\
\text { deflexus / } \\
\text { Didymograptus } \\
\text { protobifidus }\end{array}$} & \multirow[b]{2}{*}{$\begin{array}{l}\text { Baltoniodus } \\
\text { triangularis }\end{array}$} & \multirow[b]{2}{*}{$\begin{array}{l}\text { Tripodus } \\
\text { laevis }\end{array}$} & \multirow[b]{2}{*}{$\begin{array}{l}\text { Tripodus } \\
\text { laevis }\end{array}$} & \multirow[b]{2}{*}{$\begin{array}{l}\text { Baltoniodus } \\
\text { triangularis }\end{array}$} & $\begin{array}{l}\text { Microzarkodina } \\
\text { flabellum }\end{array}$ & \multirow[b]{2}{*}{$\begin{array}{l}\text { Tripodus } \\
\text { laevis s.l. }\end{array}$} \\
\hline & & & & & & & & & & & $\begin{array}{l}\text { Baltoniodus? } \\
\text { triangularis }\end{array}$ & \\
\hline & & \multirow{4}{*}{$\frac{. \frac{\pi}{\pi}}{\sqrt{x}}$} & \multirow{4}{*}{ 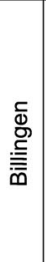 } & \multirow{4}{*}{ 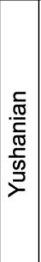 } & \multirow{4}{*}{ 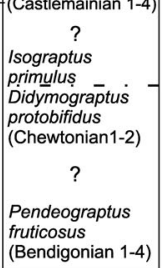 } & & \multirow{3}{*}{ - Oepikodus } & \multirow{3}{*}{ - Oepikodus_ } & \multirow{3}{*}{$\begin{array}{l}\text { Reutterodus } \\
\text { andinus }\end{array}$} & \multirow{3}{*}{$\begin{array}{l}\text { Oepikodus } \\
\text { evae }\end{array}$} & \begin{tabular}{|l|}
$\begin{array}{l}\text { Microzarkodina } \\
\text { sp. A }\end{array}$ \\
\end{tabular} & $\begin{array}{l}\text { Oepikodus } \\
\text { intermedius }\end{array}$ \\
\hline & & & & & & \multirow{2}{*}{$?$} & & & & & $\begin{array}{l}\text { Trapezognathus } \\
\text { diprion_ }\end{array}$ & \\
\hline ò & & & & & & & & & & & $\begin{array}{l}\text { Oepikodus } \\
\text { evae }\end{array}$ & $\begin{array}{l}\text { Oepikodus } \\
\text { evae }\end{array}$ \\
\hline 辇 & & & & & & $!$ & $\begin{array}{l}\text { Oepikodus } \\
\text { communis }\end{array}$ & $\begin{array}{l}\text { Prioniodus } \\
\text { elegans }\end{array}$ & $\begin{array}{l}\text { Oepikodus } \\
\text { communis }\end{array}$ & $\begin{array}{l}\text { Prioniodus } \\
\text { elegans }\end{array}$ & $\begin{array}{l}\text { Prioniodus } \\
\text { elegans }\end{array}$ & $\begin{array}{l}\text { Prioniodus } \\
\text { elegans }\end{array}$ \\
\hline
\end{tabular}

Figure 9 Biostratigraphic correlation chart for the proposed Lower/Middle Ordovician boundary (dash line) (Chinese stages after Chen Xu et al., 2001; other chronostratigraphic boundaries after Webby et al., 2004). 
Chewtonian graptolite levels in the section at Devilbend quarry, Australia; however, this record is still not verified, not published (A. VandenBerg, epist. com., 2002). Consequently, at the moment, the information that can assist the precise linkage of the FAD of $C$. aranda with graptolite records is pending further studies. Nevertheless, following recurrent records, the biohorizon corresponding to the FAD of C. aranda conclusively lies in a short interval, constrained to the uppermost Chewtonian and lowermost Castlemainian.

In Northeastern British Columbia, C. aranda ranges throughout the Jumudontus gananda and T. laevis zones or correlative intervals of the upper $O$. evae and Paroistodus originalis zones, in the matched Atlantic - Mid-continent biozonation scheme proposed by Pyle and Barnes (2002). The co-occurrence of $C$. aranda and $J$. gananda in the lowermost strata of the Sunblood Formation suggest correlation with the critical Lower/Middle Ordovician boundary interval. The same species (and interval) is present in the Road River Formation (= Sapper Formation) at section K of Tipnis et al. (1978), Northwestern Canadian Cordillera (Pohler and Orchard, 1990).

In the Baltoscandian region, $C$. aranda occurs in the upper part of the classic Oepikodus evae Zone (Löfgren, 1993), or in the Trapezognathus diprion Zone of the scheme for the Öland sections by Bagnoli and Stouge (1997), where the index species O. evae is already absent and just below the appearance of first Microzarkodina species; i.e., uppermost Latorpian Stage of the Oeland Series. This particular interval has been correlated with the upper Whitlandian Stage of the British Arenig Series (Fortey et al., 2000).

The type stratum of $C$. aranda in the Amadeus Basin, Central Australia, was roughly correlated with the O. evae and Baltoniodus triangularis - B. navis zones (Cooper, 1981). The Tabita Formation at Mount Arrowsmith, western New South Wales, Australia, with frequent records of $C$. arand $a$ and a number of common species with the Niquivil section critical interval (Ansella jemtlandica, Cornuodus longibasis, Drepanoistodus basiovalis, D. costatus, Jumudontus gananda, Oepikodus communis, Protopanderodus gradatus, $P$. leonardii, P. nogamii, and Scolopodus quadratus) was correlated with the Oepikodus evae Zone (Zhen et al., 2003).

In South China, Wang et al. (2003), reported $C$. aranda in the $B$. triangularis Zone of the Dawan Formation, Huanghuachang Section (at a locality close to this section, $C$. aranda probably ranges from the O. evae Zone, Wang Xiaofeng, epist. com., 2003). This typical species is partly illustrated by An, 1987, as Protoprioniodus costatus and $P$. aff. simplicissimus), from Southern China sections.

In the Argentine Precordillera, $C$. aranda has been reported from the diachronous top levels of the San Juan Formation and Lower Member of the Gualcamayo Formation in northern sections (Albanesi et al., 1999), and the middle part of the San Juan Formation in Central Precordillera sections, such as those at Talacasto (Albanesi, unpubl. coll.), La Silla, and Niquivil. In northwestern argentine basins, the base of the Middle Ordovician series lies close to the last record of Gothodus costulatus s.l. Lindström (= Baltoniodus crassulus andinus Rao et al.), and graptolites of the Didymograptus bifidus Zone, in the volcaniclastic Suri Formation, Famatina System, and in the siliciclastic Acoite and Sepulturas (sensu lato) formations of Eastern Cordillera (Albanesi and Ortega, 2000).

The advantage of selecting $C$. aranda compared with other species is its wide paleogeographical and environmental distribution, on the contrary to other regional guides, such as $T$. laevis or B. triangularis, which are apparently constrained to warm, or cold-water domains, respectively, or restricted to particular facies (cf., alternative GSSP proposal, the Huanghuachang section, Yichang, China, by Wang Xiaofeng et al., 2003) (Figure 9). It deems important to note that for different regions and facies some short-ranging species, such as Baltoniodus triangularis, Parapaltodus simplicissimus, Texania heligma, Trapezognathus diprion, Tripodus laevis, and first species of the genus Microzarkodina, appear close to the FAD of $C$. aranda, hence supporting an approximation of the proposed GSSP biohorizon (Figures 6, 7,9). In case of absence of $C$. aranda, the FAD of mentioned species could assist as alternative reference markers for the Lower/Middle Ordovician boundary. The LAD of following species occurs, everywhere, close to the proposed boundary biohorizon: Bergstroemognathus extensus, Juanognathus variabilis, Gothodus costulatus, Kallidontus corbatoi, Lundodus gladiatus, Oepikodus evae, Paroistodus parallelus, Protopanderodus leonardii, Protoprioniodus simplicissimus, Reutterodus andinus, Scolopodus krummi, Stolodus stola, Tropodus australis, and T. sweeti.

\section{Paleoecology}

An integrated analysis of biofacies was recently carried out by Carrera (2001). According to these studies the Niquivil section includes the Archaeorthis biofacies in the lower part of the section, the Leptellinid biofacies, which comprise the Lower/Middle Ordovician boundary, and the stromatoporoid biofacies in the uppermost part of the section. Cech and Carrera (2002) contributed detailed studies on the community replacement and distribution in the Niquivil section. Eleven communities were recognized along the section, excluding the last interval belonging to the Monorthis Zone (sequence boundary) (Figure 10).

Level bottom communities are clearly dominated by suspensive-feeders, mainly brachiopods, sponges and echinoderms. Algae and microbial communities, including calcareous cyanobacteria, represent primary producers. Girvanella, Nuia and the problematical Fisherites are the most common components of these groups. These features are similar to those of the sponge-algal facies recognized for

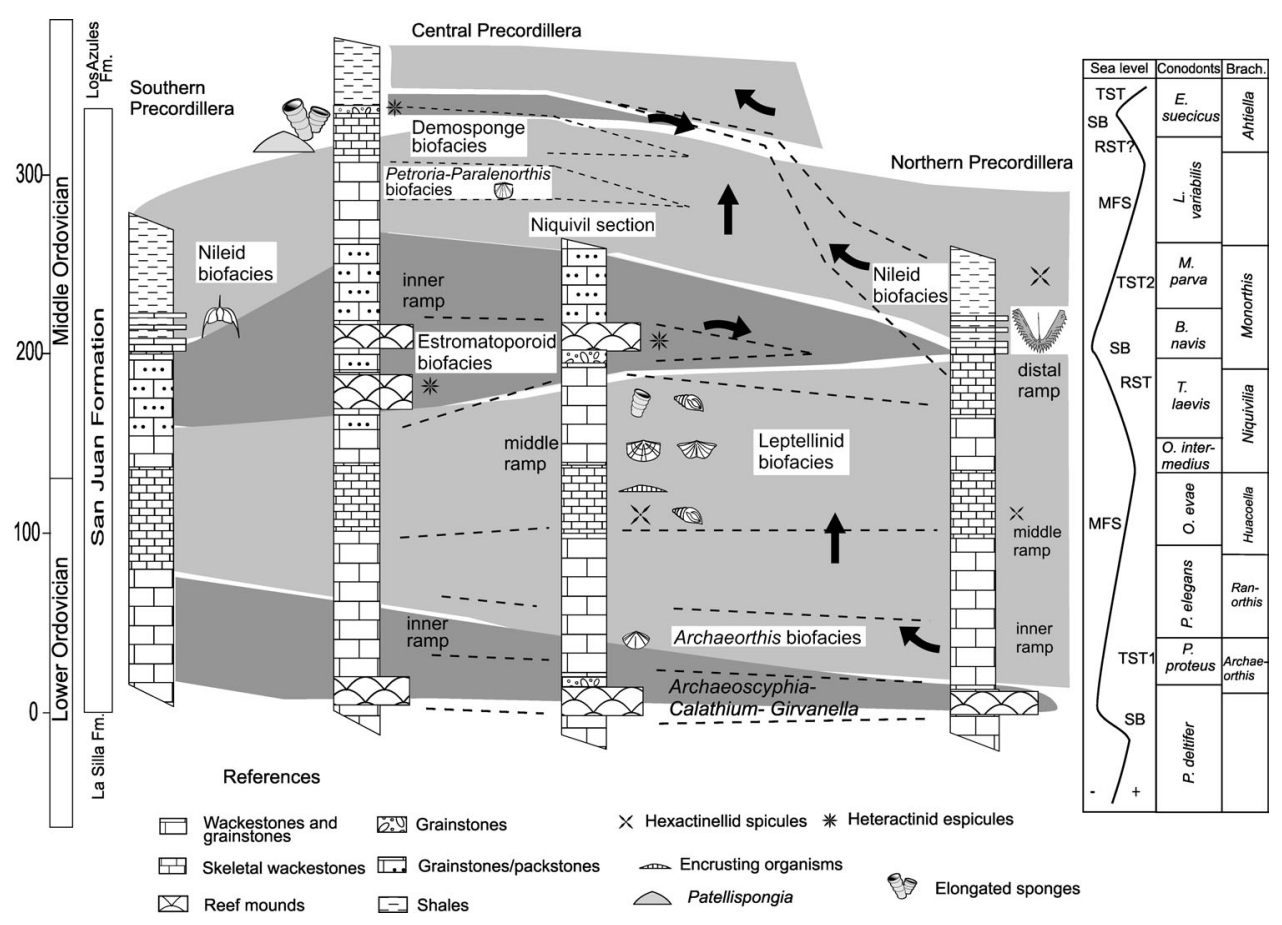

Figure 10 Distribution of biofacies of the San Juan Formation in composed stratigraphic columns through a north-south trend, showing transgressive-regressive cycles (curved arrows) and aggrading sequences (straight arrows) (modified from Cañas, 1991, and Carrera, 2001). 
equivalent Lower Ordovician carbonates recorded around the continental margin of Laurentia (Alberstadt and Repetski, 1989).

Paleoecological studies revealed a change in community structure through the Lower/Middle Ordovician boundary at Precordilleran sections (Cech and Carrera, 2002). In the uppermost Lower Ordovician communities are dominated by brachiopods, mainly Tritoechia and Huacoella, and the trilobites Annamitella and Illaenus. Other minor components are Leptella, Paralenorthis among brachipopods, and macluritacean gastropods. Biovolumetric values of the whole association show a diversified and biologically accommodated community. In the lowest Middle Ordovician, communities are less diversified and dominated by gastropods, mainly macluritaceans. Brachiopods are represented by Niquivilia, Leptella, Tritoechia, and Hesperonomia, trilobites are represented by Illaenus, and bryozoans by the laminar Nicholsonella. Few changes have been observed in the community of the succeeding interval. Minor components like the trilobite Annamitella, and the poriferans Archaeoscyphia and Allosacus, are added to the community structure, revealing minor environmental changes beyond resolution of sedimentological analysis or changes in the community dynamics.

Community replacement in the critical interval is not associated with an important environmental change and it has been considered as a change in community type (Cech and Carrera, 2002). Although this is a significant event, it is of minor magnitude compared with faunal turnovers and ecological changes in other critical points of the San Juan Formation, some of them related to sequence boundaries.

Conodont biofacial studies through the Lower/Middle Ordovician boundary interval in the San Juan Formation at the Yanso section (middle platform environments), Central Precordillera, were carried out by Albanesi (1998b). The Argentine Precordillera is a peculiar area, where mixed cold- and warm-water faunas occur in the critical boundary interval. A turnover interval in the conodont faunas occurs close to the selected boundary, where the first cycle of conodont evolution ends (late Ibexian demise sensu Sweet, 1988; cf., Albanesi and Bergström, 2004), with the extinction of significant taxa; e.g., Bergstroemognathus extensus, Juanognathus variabilis, Kallidontus corbatoi, Lundodus gladiatus, Oepikodus evae, Paroistodus parallelus, Protopanderodus leonardii, Protoprioniodus simplicissimus, Reutterodus andinus, Scolopodus krummi, Stolodus stola, Tropodus australis, and T. sweeti. A new evolutionary step in the conodont faunas is revealed by the appearance of characteristic forms within the upper O. evae to T. laevis s.l. zones, i.e., Ansella jemtlandica, Baltoniodus triangularis, Cooperignathus aranda, Costiconus costatus, Drepanoistodus basiovailis, Drepaonistodus costatus, Erraticodon sp., Fahraeusodus n. sp., Gothodus n. sp., Histiodella altifrons, Juanognathus jaanussoni, Microzarkodina sp., Oepikodus intermedius, Oistodus multicorrugatus, Paltodus jemtlandicus, Parapaltodus simplicissimus, Paroistodus originalis, Paroistodus n. sp., Protopanderodus nogamii, Pteracontiodus cryptodens, Semiacontiodus potrerillensis, Spinodus spinatus, Texania heligma, Trapezognathus sp., Tripodus laevis s.1.

Total diversity of conodont genera in the Lower/Middle Ordovician boundary biohorizon, at the Niquivil section, rise to 20 (Figures 6,7$)$. About 300 conodont elements were recovered from $5 \mathrm{~kg}$ (samples NCA + NCB) of typical wackestones and thin interbedded grainstones (Figure 3E) of the skeletal and lithoclastic facies association (middle platform). Considering similar amount of conodont elements for individual apparatuses of different genera, only 4 genera present over $10 \%$ dominance in the measured population for this environment; i.e., Protopanderodus (20\%), Oepikodus (14.5\%), Stolodus (12\%), and Juanognathus (10.7\%), while all remaining genera show a balanced proportional distribution. It interesting to note the small size that present the condont elements recovered from these samples. A contrasting distribution is registered in the deeper water facies of the Talacasto and Peña Sombría sections. The conodont fauna recovered from the correlative boundary horizon in nodular limestones facies (distal ramp), at Peña Sombría, is dominated by the genus Periodon (over 50\%), as is recurrently verified for the deep water Periodon biofacies of other regions (cf., Pohler, 1994; Johnston and Barnes, 1999). It is evident that Cooperignathus aranda becomes more frequent in deeper water facies, though not dominant (usually contributing less than $10 \%$ at species level). Typical species of the $O$. intermedius Zone from coeval shallower environments are completely replaced in same interval from deeper facies. That is the case of Oepikodus intermedius, which is apparently displaced by Gothodus n. sp. in the Peña Sombría section. Further paleoecological analysis on the community structure of the basin, should reveal significant changes that could assist for correlation over diverse paleoenvironmental settings.

\section{Isotope analyses}

The carbon isotope values in the Niquivil section record a shift from an Ibexian low of -2 per mil at the base of the sampled section to a peak of just above 0 that occurs through a $10 \mathrm{~m}$ thick interval that covers the proposed base of the Middle Ordovician (Figure 4). Controlled values at La Silla section are similar to Niquivil and suggest the recorded trends are regional in scope (Figure 11). The trends in the Argentina sections are consistent with the carbon isotope stratigraphy obtained across the Ibexian-Whiterockian boundary at a well-studied section near Shingle Pass, NV, in which most analyzed samples fall between -1 and 0 per mil. The local peak above 0 may ultimately be used for high-resolution correlation of carbonate-rich sections on other continents, either as an independent check on the conodont biostratigraphy or as the sole means of picking the boundary interval in sparsely fossiliferous sequences. In addition, if these trends are shown to be of global significance, it suggests that the burial ratio of organic carbon to carbonate carbon is likely to have increased during this time period. Perhaps a eustatic drop increased the flux of riverine phosphorous to the global oceans and stimulated relatively high rates of primary productivity in the lower Middle Ordovician.

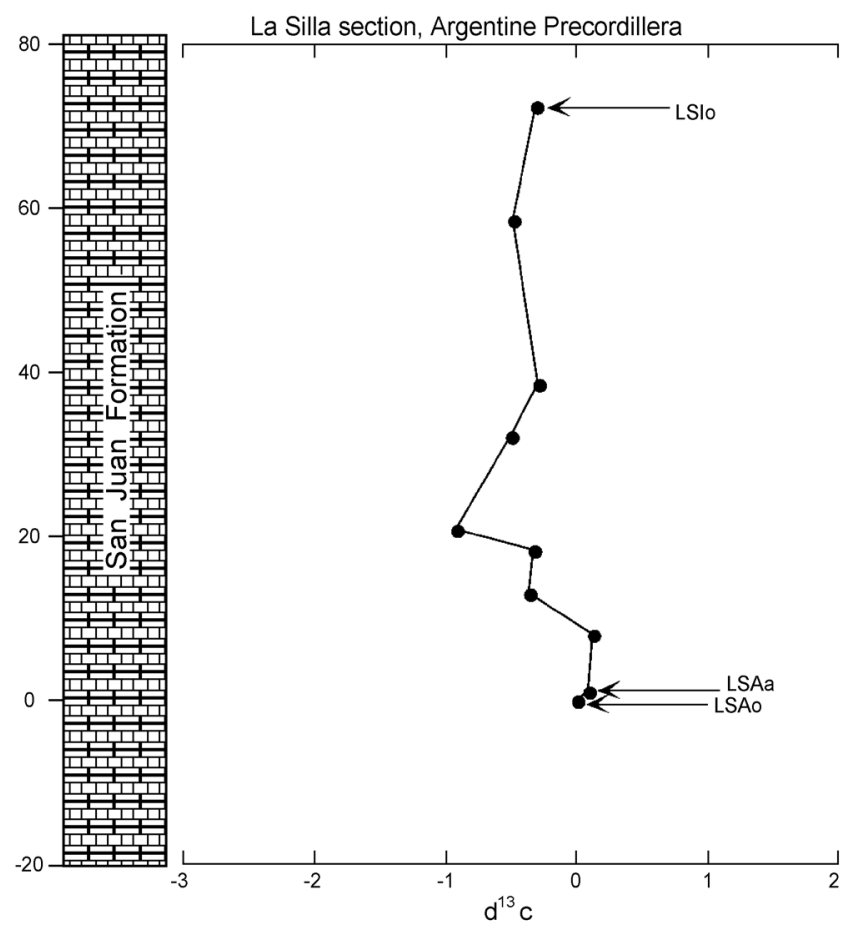

Figure 11 Carbon isotope curve of the La Silla section. Note that level 0 is approximately correlative with level NCA of the Niquivil section, which marks the Lower/Middle Ordovician boundary.

\section{Radiometric dating}

New K-bentonite samples, interbedded with carbonate strata yielding lower records of $\mathrm{C}$. aranda, whose heavy mineral suite proved suitable for radiometric dating, were recovered from the auxiliary Talacasto section of the Argentine Precordillera. They yielded 
a mean of $469.8 \pm 2.3 \mathrm{Ma}$ (U-Pb SHRIMP dating by Baldo et al., 2003). Sampling for K-bentonites is not possible in the Niquivil section because the bentonite is amalgamated with carbonate sediment. Heavy mineral concentrations from samples NB, NC (NCA in coincidence with the FAD of $C$. aranda) and ND from the critical boundary interval have the potential for being dated radiometrically. $\mathrm{K}$ bentonites in the boundary interval in the Peña Sombría auxiliary section also have the potential for providing radiometric dates (see below).

\section{Auxiliary sections}

\section{La Silla section}

La Silla section is situated $12 \mathrm{~km}$ north of the Niquivil section and $3 \mathrm{~km}$ from the $40 \mathrm{road}$ (Figure 1). This section constitutes the northern extension of the range and is quite more complete, stratigraphically, than the Niquivil section because Upper Cambrian to Middle Ordovician limestones are represented.

Upper Cambrian rocks constitute the La Flecha Formation, and Tremadocian limestones correspond to the La Silla Formation. A 4 $\mathrm{m}$ thick sequence of microbial boundstones, including sponges and calathids (Cañas and Carrera, 1993), represents the base of the San Juan Formation, at the uppermost Tremadocian (Paltodus deltifer deltifer Subzone of the P. deltifer Zone). After this interval, a 25 meter thick succession of intercalated wackestones and grainstones, with conodonts of the Paroistodus proteus Zone occurs. These levels include chert nodules and silicified shell pavements mainly composed by brachiopods (Archaeorthis) and gastropods. There are no outcrops of this lower interval in the Niquivil section. After that, the stratigraphic succession in La Silla section that begins with the $P$. elegans Zone is fairly well correlated with the Niquivil section. No physical evidence for discontinuity has been recognized within the section. The outcrops of both Niquivil and La Silla culminate in the Baltoniodus navis Zone (Monorthis brachiopod Zone) where the section is covered by Quaternary sediments.

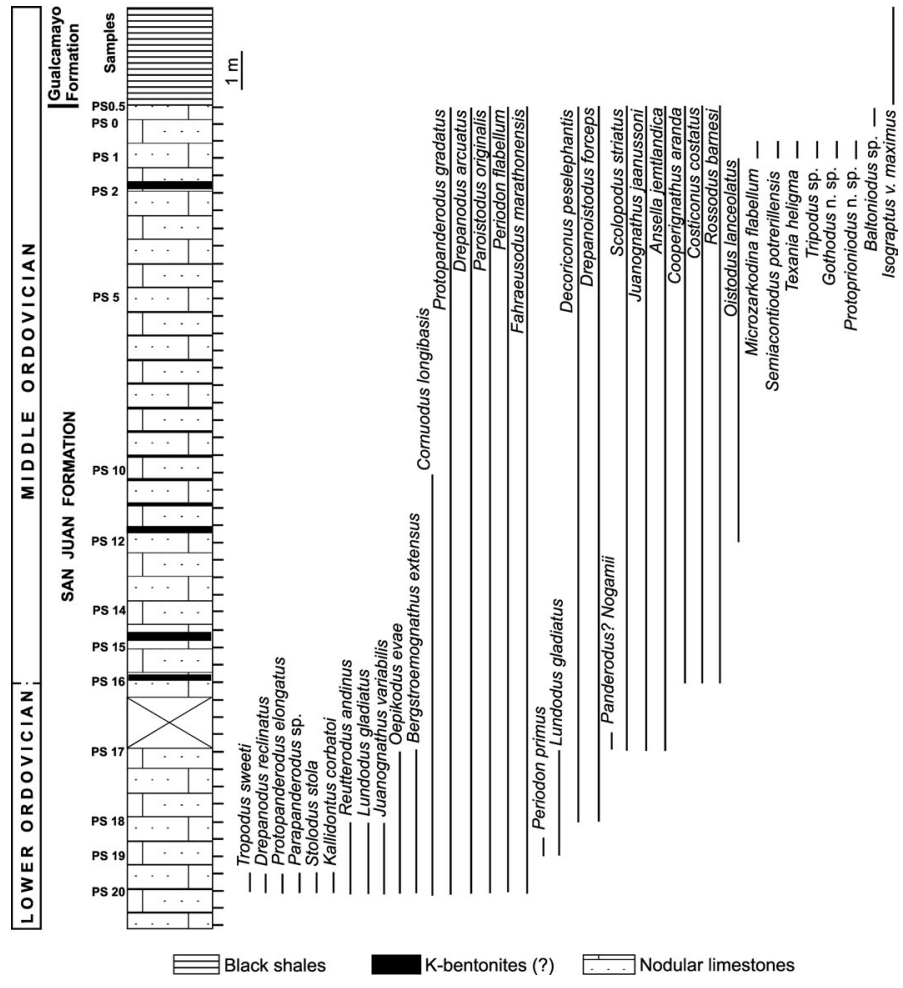

Figure 12 Conodont species ranges of the Peña Sombría profile through the critical Lower/Middle Ordovician boundary interval.
Conodont samples were sparsely collected, primarily for biozonal control of the critical Lower/Middle Ordovician boundary interval. 8 processed samples ( $2 \mathrm{~kg}$ each one) were taken from a 50 $\mathrm{m}$ thick interval, and yielded a similar association and preservation of species to that of the Niquivil section. Conodont data reveal that the Oepikodus evae, O. intermedius, and B. navis zones are present in the middle-upper part of the La Silla section. A similar high resolution biostratigraphy is expected in case further studies deem detailed sampling. A conodont collection from the lowest Middle Ordovician $O$. intermedius Zone includes: Cooperignathus aranda, Juanognathus jaanussoni, Oepikodus intermedius, Oistodus lanceolatus, Semiacontiodus potrerillensis, Paroistodus originalis Periodon flabellum, Protopanderodus elongatus, Protopanderodus gradatus, Rossodus barnesi, and Drepanodus arcuatus. The approximate position of the Lower/Middle Ordovician boundary is ca. $80 \mathrm{~m}$ below the top of the La Silla section.

\section{Peña Sombría section}

The Peña Sombría section is exposed along the Guandacol River. It is located about $20 \mathrm{~km}$ to the west of Guandacol town, in La Rioja Province, near the border with San Juan Province (Figure 1). This is the northernmost known section of the Precordillera that includes strata from the critical Lower/Middle Ordovician boundary interval. The measured section is $43 \mathrm{~m}$ thick, and is partly folded at the base. It interbeds the lowest K-bentonite levels of the Precordillera, within the upper Oepikodus evae Zone, which could provide potential radiometric dating for the boundary horizon. The registered conodont fauna proceeds from distal ramp carbonate facies, showing the composition of conodont assemblages for high resolution correlation of deep water environments (Figure 12).

From sample PS 5, located about $12 \mathrm{~m}$ below the top of the San Juan Formation, the interval includes the FAD of Cooperignathus aranda at the base, and the following associated species: Ansella jemtlandica, Cornuodus longibasis, Costiconus costatus, Decoriconus peselephantis, Drepanodus arcuatus, Drepanoistodus basiovalis, Drepanoistodus forceps, Fahraeusodus marathonensis s.1., Gothodus n. sp., Juanognathus jaanussoni, Paroistodus originalis, Paroistodus parallelus, Periodon flabellum, Protopanderodus gradatus, Rossodus barnesi, Semiacontiodus potrerillensis, Scolopodus quadratus, Texania heligma, Tripodus sp. In the lower sample PS 4, $3 \mathrm{~m}$ below the previous one, the genus Microzarkodina does appear for the first time (Figure 12). Due to the preliminary sampling of present contribution, the boundaries of the conodont zones are not herein defined. Notwithstanding this, and the apparent absence of Oepikodus intermedius due to facies control, the conodont records suggest the upper $15 \mathrm{~m}$ of the profile should correspond to the $O$. intermedius Zone, succeeding the $O$. evae Zone near the FAD of $C$. aranda.

The Peña Sombría section is about $5 \mathrm{~km}$ west of Los Sapitos section, in same study area, where the first conodont-graptolite biozonation for northern Argentine Precordillera was carried out (Albanesi et al., 1999; Ortega and Albanesi, 1999). Lower Middle Ordovician graptolites of the Peña Sombría section were recovered from the basal levels of the Gualcamayo Formation, where limestone strata are interbedded with graptolitic black shale. The graptolite assemblage represents the Isograptus victoriae maximus Zone (Ortega et al., 1985), which approximately correlates with the Tripodus laevis s.l. Zone.

Conodonts from the Peña Sombría section exhibit CAI 4-5, which represent deep overburden, within anchizone to epizone thermal maturation levels.

\section{Talacasto section}

The Talacasto section is situated $15 \mathrm{~km}$ west of $40 \mathrm{road}$ and 50 $\mathrm{km}$ north of San Juan city (Figure1). The stratigraphic section is placed in the Talacasto gulch along the Talacasto-Iglesia road. The whole road cut section is slightly folded and faulted, however, it shows good outcrops of the middle part of the San Juan formation. 
The $55 \mathrm{~m}$ thick studied section includes the Oepikodus intermedius, Tripodus laevis s.l., and Baltoniodus navis zones (regarding local brachiopod biostratigraphy, it represents the upper part of the Huacoella radiata Zone, and the Niquivilia extensa and Monorthis cumillangoensis zones). The Talacasto section is selected as auxiliary for its distinctive basal Middle Ordovician conodont fauna, which is useful for long distance correlation in deeper platform environments, and for the presence of $\mathrm{K}$-bentonites that can assist for radiometric dating.

The investigated interval, which is exposed along the road that connects the localities of Baños de Talacasto with Ancha Creek (where limestones are interbedded with thick K-bentonite levels), already correspond to the Oepikodus intermedius Zone (Oepikodus evae is not present). Although the passage through the Lower/Middle Ordovician boundary is lost in this particular section, it includes lowermost Middle Ordovician levels with well preserved faunas. Lowest strata contain a significant conodont association that reveals the base of the Middle Ordovician Series, as defined in the Niquivil section. In particular, the tight overlapping of Cooperignathus aranda, Cooperignathus nyinti, Drepanoistodus basiovalis, Drepanoistodus forceps, Juanognathus jaanussoni, Oistodus multicorrugatus, Paroistodus originalis, Oepikodus intermedius, Lundodus gladiatus, Stolodus stola, Texania heligma, Tropodus australis, and Paroistodus n. sp., can assist this dating. Other long ranging taxa recorded in the section are: Periodon flabellum, Oistodus lanceolatus, Protopanderodus gradatus, Rossodus barnesi, and Cornuodus longibasis. The conodont assemblage appears to include a similar composition of species but different proportions; for example, the higher abundance of the pelagic open-water species of Periodon indicates deeper platform depositional environments than correlative intervals in the Niquivil section. Conodonts are well-preserved with CAI 3, which demonstrates deeper overburden levels for this tectonic thrust in relation to the Niquivil section.

\section{Conclusions}

All attributes required for a GSSP by the International Commission on Stratigraphy (IUGS) (Remane et al., 1996) are met by the Niquivil Section:

- The exposure covers an adequate thickness, and the time interval is sufficiently represented so that the boundary can also be determined by means of auxiliary markers at or close to the boundary.

- Sedimentation is continuous across the boundary interval, with no evidence of sedimentary breaks or condensation.

- The rate of sedimentation was high enough to record successive events that straddle the boundary.

- The boundary interval is not affected by synsedimentary and significant tectonic disturbances. The Niquivil section represents a whole thrust bounded by major faults at base and top, but no significant displacements or deformations are visible within the stratigraphic section of about $200 \mathrm{~m}$ thick.

- There is no metamorphism, nor a strong diagenetic signal. Conodont Color Alteration Index is 1.5-2, demonstrating low overburden paleotemperatures, within the diagenetic zone.

- Macrofossils are well-preserved, especially brachiopods and trilobites, and microfossils, especially conodonts, are too.

- The conodont biostratigraphy based on high resolution sampling demonstrates that there is no faunal break in the critical boundary interval, and the boundary itself is located with high stratigraphic precision (at the FAD of Cooperignathus aranda, in the uppermost part of the Oepikodus evae Zone; i.e., $100.15 \mathrm{~m}$ above the base of the section, or $43.65 \mathrm{~m}$ below the basal level (NK) of the patch reefs-shoal interval that occurs at the top of the section).

- There are no significant vertical facies changes for about $40 \mathrm{~m}$ above the proposed boundary, and for more than $70 \mathrm{~m}$ below the proposed boundary.

- The open platform facies, in the globally recognized Oepikodus evae Zone flooding event, plus abundant macro- and microfossils represents a favourable facies and eustatic state for long distance correlation, as does the paleobiogeographic setting of the Argentine Precordillera, in the passage zone between the North American Midcontinent and Atlantic conodont realms, though including mixed faunas.

- The proposed GSSP preserves an excellent carbon-isotope record that provides an auxiliary marker of potential global application in the marine pelagic realm. The Niquivil section also has the potential for characterization of the boundary interval by other stable or radiogenic isotopes.

- Radiometric dating of horizons above the boundary but within the boundary interval is available from the auxiliary Talacasto section, and these horizons can be accurately correlated by means of the proposed conodont key species. Strata from the critical boundary interval in the Niquivil section provided heavy minerals that afford opportunities for additional radiometric dating.

- The Niquivil section is readily accessible by road, with free access.

- The preservation potential of the section is optimal considering it is located in public land, which could eventually be declared a protected area, as reference site for future studies.

\section{Acknowledgments}

The authors acknowledge continued support by CONICET (PIP 0933/98), and a special grant by SOS (ICS-IUGS) for present project. G. Ortega and S. H. Peralta assisted in field work. Drs. S. M. Bergström, S. C. Finney, and G. Bagnoli reviewed a preliminary version of the manuscript providing helpful suggestions.

\section{References}

Aigner, T. 1985. Storm Depotitional Systems. Lectures Notes in Earth Sciences 3, Springer Verlag, 3: 1-174.

Albanesi, G.L. 1998a. Taxonomía de conodontes de las secuencias ordovícicas del cerro Potrerillo, Precordillera Central de San Juan, R. Argentina. Actas XII Academia Nacional de Ciencias, Córdoba: 101-253.

Albanesi, G.L. 1998b. Biofacies de conodontes de las secuencias ordovícicas del cerro Potrerillo, Precordillera Central de San Juan, R. Argentina. Actas XII Academia Nacional de Ciencias, Córdoba: 75-98.

Albanesi G.L. and Bergström, S.M. 2004. Conodonts: Lower to Middle Ordovician record. in B.D. Webby, F. Paris, M.L. Droser and I. G. Percival, eds, The Great Ordovician Biodiversification Event. Columbia University Press. New York: 312-336.

Albanesi, G.L. and Carrera, M.G. 2001. Niquivil Section of Central Precordillera, Argentina, proposed as the Global Stratotype for the base of the Middle Ordovician Series. Geological Society of America Annual Meeting, Boston, Abstracts: A446.

Albanesi, G.L., Carrera, M.G., Cañas, F. and Saltzman, M. 2003. The Niquivil Section, Precordillera of San Juan, Argentina, Proposed GSSP for the Lower/Middle Ordovician boundary. in G.L. Albanesi, M.S Beresi and S.H. Peralta, eds, Ordovician from the Andes, Proceedings of the 9th International Symposium on the Ordovician System, San Juan, Argentina. Serie Correlación Geológica 17, INSUGEO, Tucumán: 33-40.

Albanesi, G.L, Hünicken, M. and Barres, C.R. 1998a. Bioestratigrafía de conodontes de las secuencias ordovícicas del Cerro Potrerillo, Precordillera central de San Juan, R. Argentina. Actas XII Academia Nacional de Ciencias, Córdoba: 7-72.

Albanesi, G.L. and Ortega, G. 2000. The North American Ibex-Whiterock boundary correlated in the Ordovician System of Argentina. "Summit 2000", Geological Society of America annual meeting. Reno, Nevada. Abstract with Programs A 32 (7): 391.

Albanesi G.L. and Ortega, G. 2002. Advances on conodont-graptolite biostratigraphy of the Ordovician System of Argentina. in F.G. Aceñolaza (ed.). Aspects on the Ordovician System in Argentina. In: Aceñolaza, F.G., ed, Aspects on the Ordovician System in Argentina. Serie Correlación Geológica 16, INSUGEO, Tucumán: 143-165.

Albanesi, G.L., Ortega, G., Barnes, C.R. and Hünicken, M.A. 1999. Conodont-graptolite biostratigraphy of the Gualcamayo Formation (Middle Ordovician) in the Gualcamayo-Guandacol rivers area, Argentina Precordillera. in P. Kraft and O. Fatka, eds, Quo Vadis Ordovician? Short 
papers of the 8th International Symposium on the Ordovician System, Prague, Acta Univesitatis Carolinae - Geologica 43 (1/2): 45-48.

Albanesi G.L., Ortega, G. and Hünicken, M.A.. 1998b. High resolution conodont-graptolite biostratigraphy controlling the diachronous boundary between the San Juan and Gualcamayo formations (Arenig-Llanvirn) in the Argentine Precordillera. ECOS VII (Seventh International Conodont Symposium Held in Europe), Bologna-Modena, Italia. Abstracts: 2-4

Alberstadt, L. and Repetski, J.E. 1989. A Lower Ordovician sponge/algae facies in the southern United States and its counterparts elsewhere in North America. Palaios, 4: 225-242.

An, T.-X. 1987. The Lower Paleozoic conodonts of South China. Peking University Publication House, Beijing: 1-238.

Astini, R.A. 1993, Secuencias deposicionales y niveles del mar en el Sistema Ordovícico de la Precordillera Argentina: Boletín de la Real Sociedad Española de Historia Natural (Sec. Geol.), 88: 113-126.

Bagnoli, G. and Stouge, S. 1997. Lower Ordovician (Billingenian-Kunda) conodont zonation and provinces based on sections from Horns Udde, north Öland, Sweden. Bollettino della Società Paleontologica Italiana, 35: 109-163.

Baldis, B.A.J. 1979. Ensayo de análisis paleoecológicos con trilobites ordovícicos argentinos. Ameghiniana, 15 (1-2): 3-14.

Baldo, E.G., Fanning, C.M., Rapela, C.W., Pankhurst, R.J., Casquet, C. and Galindo, C. 2003. U-Pb shrimp dating of rhyolite volcanism in the Famatinian belt and k-bentonites in the Precordillera. In Albanesi, G.L., M.S Beresi and S.H. Peralta, eds. Ordovician from the Andes. Proceedings of the 9th International Symposium of the Ordovician System, Serie Correlación Geológica 17, INSUGEO, Tucumán: 185-190.

Benedetto, J.L. 1998. Early Paleozoic braquiopods and associated shelly faunas from western Gondwana; its bearing on the geodynamic history of the pre Andean margin: en Pankhurst, R. and Rapella, C.W., (eds.), The Proto-Andean margin of Gondwana: Geological Society, Special Publication. 142: .57-83.

Benedetto, J.L. 2002. The Ordovician brachiopod faunas of Argentina: Chronology and biostratigraphic succession. in F.G. Aceñolaza, ed, Aspects on the Ordovician System of Argentina. INSUGEO, Tucumán, Serie Correlación Geológica 16: 87-106.

Benedetto, J.L., Cañas, F. and Astini, R. 1986. Braquiópodos y trilobites de la zona de transición entre las Formaciones San Juan y Gualcamayo en el área de Guandacol (La Rioja, Argentina). IV Congreso Argentino de Paleontología y Bioestratigrafía, Mendoza, Actas, 1: 103-111.

Bergström, S.M. 1995. The search for global biostratigraphic reference levels in the Ordovician System: regional correlation potential of the base of the North American Whiterockian Stage. in Cooper, J.D.; Droser, M.L. and Finney, S.C., eds, Ordovician Odyssey: Short Papers for the Seventh International Symposium on the Ordovician System, Las Vegas, SEPM, Fullerton: 149-152.

Berry, W.B.N. 1960. Graptolite faunas of the Maratón region, West Texas. University of Texas Pubilcation 6005, 1-179.

Cañas, F.L. 1995. Early Ordovician Carbonate platform facies of the Argentine Precordillera: restricted shelf to open plataform evolution. in Fullerton, Cooper, J.D.,Drosser, M.K. and Finney, S.C., eds, Seventh International Symposium on Ordovician System. The pacific secton Society for Sedimentary Geology (SEPM), Book 77:221-224

Cañas, F.L. 1999. Facies and sequences of late Cambian-early Ordovician carbonates of the Argentina Precordillera: A stratigraphic comparation whit Laurentia platforms. in Keppie D. and Ramos, V., eds, LaurentiaGondwana connections before Pangea: Geological Society of America Special paper, 336: 43-62.

Cañas, F.L. and Carrera, M.G. 1993. Early Ordovician microbial-spongereceptaculitid bioherms of the Precordillera, Western Argentina. Facies 29:169-178

Cañas, F.L. and Keller, M. 1993. Arrecifes y montículos arrecifales en la Formación San Juan (Precordillera Sanjuanina, Argentina): Los arrecifes más antiguos de Sudamérica. Boletín Real Sociedad Española de Historia Natural (Sec. Geología), 88 (1-4): 127-136.

Carrera, M.G. 1991. Los géneros Selenoides Owen y Calathium Billings (Receptaculitaceae) en el Ordovícico de la Precordillera de San Juan, Argentina. Ameghiniana, 28: 375-380

Carrera, M.G. 1997. Significado paleoambiental de los poríferos y briozoos de la Formación San Juan (Ordovícico), Precordillera Argentina. Ameghiniana, 34 (2): 179-199.

Carrera, M.G., 2001. Análisis de la distribución y composición de las biofacies de la Formación San Juan (Ordivícico Temprano), Precordillera Argentina. Ameghiniana, 38: 169-184

Carrera, M.G., Sánchez, T.M. and Benedetto, J.L. 1999. Paleoenvironmental controls on biofacies in the Early Ordovician limestones of the Argentine Precordillera. Acta Universitatis Carolinae, Geologica, 43:475-477.
Cech, N. and Carrera, 2002. Dinámica de las comunidades arenigianas de la Formación San Juan (Ordovícico), precordillera argentina. Ameghiniana, 39: 21-40

Chen $\mathrm{Xu}$, Zhou Zhi-Yi, Rong Jia-Yu and Li Jun. Ordovician seires and stages in Chinese stratigraphy: steps toward a global usage. Alcheringa 25: 131141

Church, S.B. 1974. Lower Ordovician patch reefs in western Utah. Brigham Young Univ. Geol. Studies, 21/3: 41-62.

Cooper, B.J. 1981. Early Ordovician conodonts from the Horn Valley Siltstone, central Australia. Palaeontology, 24(1): 147-183.

Dattilo, B.F. 1993. The Lower Ordovician Fillmore Formation of western Utah: storm-dominated sedimentation on a passive margin. Brigham Young Univ. Studies in Geology, 39: 71-100.

Epstein, A.G., Epstein, J.B. and Harris, L.D. 1977. Conodont color alteration - An index to organic metamorphism. United States Geological Survey Professional Paper, 995: 1-27.

Ethington, R.L. and Clark, D.L. 1971. Lower Ordovician conodonts in North America. in Sweet, W.C. and Bergström, S.M., eds, Symposium on conodont biostratigraphy. Geological Society of America Memoir, 127: 63-82.

Ethington, R.L. and Clark, D.L. 1981. Lower and Middle Ordovician conodonts from the Ibex area, western Millard County, Utah. Brigham Young University Geology Studies, 28 (2): 1-160.

Fåhraeus, L.E . and Roy, K . 1993. Conodonts from the Cambro-Ordovician Cooks Brook and Middle Arm Point Formations, Bay of Islands, weste rn Newfoundland. Geologica et Palaeontologica, 27, 1-53.

Finney, S.C. and Ethington, R.L. 1992. Whiterockian graptolites and conodonts from the Vinini Formation, Nevada: Biostratigraphic implications. in Webby, B.D. and Laurie, J.R., eds, Global Perspectives on Ordovician Geology, Balkema, Rotterdam: 153-169.

Finney, S.C. and Ethington, R.L. 1995. Base of Whiterock Series correlates with base of Isograptus victoriae lunatus Zone in Vinini Formation, Roberts Mountains, Nevada. in Cooper, J.D.; Droser, M.L. and Finney, S.C., eds,. Ordovician Odyssey: Short Papers for the Seventh International Symposium on the Ordovician System, Las Vegas, SEPM, Fullerton: $153-156$

Finney, S.C. and Ethington, R.L. 2000a. Global Ordovician Series boundaries and global event horizons, Monitor Range and Roberts Mountains, Nevada. in Legeson, D.R., Peters, S.G. and Lahern, M.M., eds, Great Basin and Sierra Nevada. Boulder, Colorado, Geol. Soc. Am. Field Guide 2: 301-318.

Finney, S.C. and Ethington, R.L. 2000b. Whiterock Narrows Section, Monitor Range, Nevada, proposed as the Global Stratotype for the base of the Middle Ordovician Series. Geological Society of America Annual Meeting, Reno, Abstracts: A391

Finney, S.C., Gleason, J., Gehrels, G., Peralta, S. and Aceñolaza, G. 2003. Early Gondwanan connection for the Argentine Precordillera terrane. Earth and Planetary Science Letters, 205: 349-359.

Fortey, R.A. 1975. Early Ordovician trilobite communities. Fossils and Strata 4: $339-360$

Fortey, R.A., Harper, D.A.T., Ingham, J.K., Owen, A.W., Parkes, M.A. Rushton, A.W.A. and Woodcock, N.H. 2000. A revised correlation of Ordovician rocks in the British Isles. The Geological Society. Special Report, 24: 1-83.

Herrera, Z. and Benedetto, J.L. 1991. Early Ordovician brachiopod faunas of the Precordillera basin, Western Argentina: Biostratigraphy and paleobiogeographical afinities. in MacKinnon, L. and Campbell, J., eds, Brachiopods trhough time, A.A. Balkema press: 283-301.

Hünicken, M. and Ortega, G. 1987. Lower Llanvirn-Lower Caradoc (Ord.) conodonts and graptolites from the Argentine Precordillera. $4^{\circ}$ European Conodont Symposyum, Nottingam: 136-145

Izold, M.D. 1993. Early Ordovician shelf-slope conodont biostratigraphy and biofacies differentiation of western Iapetus in West Texas and New York. Unpublished M.Sc. thesis, The Ohio State University, 1-220.

Ji, Z. and Barnes, C.R. 1994. Lower Ordovician conodonts of the St. George Group, Port au Port Peninsula, western Newfoundland, Canada. Palaeontographica Canadiana, Geological Association of Canada and Canadian Society of Petroleum Geologists, Calgary, 11: 1-149.

Johnston, D.I. and Barnes, C.R. 1999, 2000. Early and middle Ordovician (Arenig) conodonts from St. Pauls Inlet and Martin Point, Cow Head Group, western Newfoundland, Canada; 1-2. Biostratigraphy and paleoecology. Geologica et Palaeontologica, 33: 21-70.

Keller, M. 1999. Argentine Precordillera. Sedimentary and Plate Tectonic History of a Laurentian Crustul Fragment in South America. Geological Society of America, Special Paper 341: 1-131.

Keller, M., Buggish, W., and Lehnert, O. 1998, The stratigraphic record of the Argentine Precordillera and its plate-tectonic background: in 
Pankhurst, S.L., and Rapela, C.W. (eds.), The Proto-Andean margin of Gondwana: Geological Society of London, Special Publications no. 142, p. 35-56.

Keller, M., Cañas, F.L., Lehnert,O. and Vaccari, N.E. 1994. The Upper Cambrrian and Lower Ordovician of the Precordillera (Western Argentina): Some stratigraphic reconsiderations. Newsletter on Stratigraphy, 31(2):115-132.

Keller, M. and Flügel, E. 1996. Early Ordovician reefs from Argentina: stromatoporoid vs. stromatolite origin. Facies 34: 177-192.

Kreisa, R.D. 1981. Storm-generated sedimentary structures in subtidal marine facies with examples from the middle Ordovician of southwestern Virginia. Jour. Sed. Petrol., 51: 823-848.

Lehnert, O. 1993. Bioestratigrafía de los conodontes arenigianos de la Formación San Juan en la localidad de Niquivil (Precordillera sanjuanina, Argentina) y su correlación intercontinental. Revista Española de Paleontología, 8 (2): 153-164.

Lehnert, O. 1995a. Ordovizische Conodonten aus der Präkordillere Westargentiniens: Ihre Bedeutung für Stratigraphie und Paläogeographie. Erlanger Geologische Abhandlungen, 125: 1-193.

Lehnert, O. 1995b. Geodynamic processes in the Ordovician of the Argentine Precordillera: New biostratigraphic contraints. In: Cooper, J., Droser, M. L. and Finney, S. C. (eds.), Seventh International Symposium on the Ordovician System. The Pacific section Society for Sedimentary Geology (SEPM), Fullerton, Book 77: 75-79.

Lehnert, O. and Keller, M. 1993. Posición estratigráfica de los arrecifes arenigianos en la Precordillera Argentina. Docum. Lab. Géol. Lyon, 125: 263275.

Lindström, M. 1971. Lower Ordovician conodonts of Europe. Geological Society of America, Memoir 127:21-61.

Löfgren, A. 1978. Arenigian and Llanvirnian conodonts from Jämtland, northern Sweden. Fossils and Strata, 13: 1-129.

Löfgren, A. 1993. Arenig conodont successions from central Sweden. Geologiska Föreningens I Stockholm Förhandlingar, 115, 3: 193-207.

Maletz, J., Mitchell, C.E., Melchin, M.J. and Dunlavey, T. 2003. Revision of the Castlemainian isograptid (graptolite) biostratigraphy in western Newfoundland. in Ortega, G. and Aceñolaza, eds, G.F. Proceedings of the 7th International Graptolite Conference and Field Meeting of the International Subcommission on Silurian Stratigraphy. Serie Correlación Geológica, INSUGEO, Tucumán: 55-60.

Markello, J.R. and Read, J.F. 1981. Carbonate ramp-to-deeper shale shelf transitions of an Upper Cambrian intrashelf basin, Nolichucky Formation, Southwest Virginia Appalachians. Sedimentology, 28: 573-597.

Ortega, G. and Albanesi, G.L. 1999. Graptolite biostratigraphy of the Gualcamayo Formation (Middle Ordovician) at the Los Sapitos creek section, Argentina Precordillera. in P. Kraft and O. Fatka, eds, Quo Vadis Ordovician? Short papers of the 8th International Symposium on the Ordovician System, Prague, Acta Univesitatis Carolinae - Geologica 43 (1/2): 49-52.

Ortega, G. and Albanesi, G.L. 2000. Graptolitos de la Formación Gualcamayo (Arenigiano-Llanvirniano) en el cerro Potrerillo, Precordillera Central de San Juan, Argentina. Boletín de la Academia Nacional de Ciencias, Córdoba. 64: 27-60.

Ortega, G., Cañas, F. and Hünicken, M.A. 1985. The occurrence of Isograptus victoriae Harris in the Gualcamayo Formation, Guandacol, La Rioja Province, Argentina. Boletín de la Academia Nacional de Ciencias, Córdoba, Argentina, 56 (3-4): 127-133.

Ottone, E.G., Albanesi, G., Ortega, G. and Holfeltz, G. 1999. Palynomorphs, conodonts and associated graptolites from the Ordovician Los Azules Formation, Central Precordillera, Argentina. Micropaleontology, 45 (3): 225-250.

Pohler, S.M.L. 1994. Conodont biofacies of Lower to lower Middle Ordovician Mega-conglomerates, Cow Head Group, Western Newfoundland. Geological Survey of Canada Bulletin, 459: 1-71.

Pohler, S.M.L. and Orchard, M.J. 1990. Ordovician conodont biostratigraphy, western Canadian Cordillera. Geological Survey of Canada Paper, 15: $1-37$.

Pratt, B.R. 2001. Calcification of cyanobacterial filaments: Girvanella and the origin of lower Paleozoic lime mud. Geology, 29: 763-766.

Pyle, L.J. and Barnes, C.R., 2002. Taxonomy, evolution, and biostratigraphy of conodonts from the Kechika Formation, Skoki Formation, and Road River Group (Upper Cambrian to Lower Silurian), Northeastern British Columbia. NRC Research Press, Ottawa, Ontario, Canada, 1-227.

Remane, J., Bassett, M.G., Cowie, J.W., Gohrbandt, K.H., Lane, H.R., Michelsen, O. and Naiwen, W. 1996. Revised guidelines for the establishment of global chronostratigraphic boundaries by the International Commission on Stratigraphy (ICS). Episodes, 19: 77-80.
Repetski, J.E. 1982. Conodonts from El Paso Group (Lower Ordovician) of westernmost Texas and southern New Mexico. New Mexico Bureau of Mines and Minera Resources Memoir, 40: 1-121.

Repetski, J.E., Harris, A.G. and Stamm, N.R. 1995. An overview of conodonts from New Jersey. in Baker, J.E.B., ed, Contributions to the Paleontology of New Jersey. Geol. Assoc. New Jersey, XII: 192-208.

Ross, R.J. Jr. and Ethington, R.L. 1991. Stratotype of Ordovician Whiterock Series. Palaios, 6: 156-173.

Ross, R.J. Jr., Hintze, L.F., Ethington, R.L., Miller, J.F., Taylor, M.E. and Repetski, J.E. 1997. The Ibexian, Lower most Series in the North American Ordovician. U. S. Geological Survey Professional Paper, 1579: 150 .

Sánchez, T.M., Carrera, M. and Benedetto, J.L. 1996. Variaciones faunísticas en el techo de la formación San Juan (Ordovícico temprano, Precordillera argentina): Significado paleoambiental. Ameghiniana, 33 (2): 185-200.

Serpagli, E. 1974. Lower Ordovician conodonts from Precordilleran Argentina (Province of San Juan). Bolletino della Società Paleontologica Italiana, 13(1-2): 17-98.

Stait, K. and Druce, E.C. 1993. Conodonts from the Lower Ordovician Coolibath Formation, Georgina Basin, central Australia. Bureau of Mineral Resources Journal of Australian Geology and Geophisics, 13: 293- 322.

Sweet, W.C. 1988. The Conodonta: Morphology, taxonomy, paleoecology, and evolutionary history of a long-extinct animal phylum. Oxford monographs on geology and geophysics, Oxford University Press, New York, 10: $1-212$

Sweet, W.C., Ethington, R.L. and Barnes, C.R. 1971. North American Middle and Upper Ordovician conodont faunas. in Sweet, W.C. and Bergström, S.M., eds,. Symposium on conodont biostratigraphy. Geological Society of America Memoir, 127: 163-193.

Sweet, W.C. and Tolbert, C.M. 1997. An Ibexian (Lower Ordovician) Reference Section in the Southern Egan Range, Nevada, for a Conodon-Based Chronostratigraphy. U. S. Geological Survey Professional Paper, 1579: 53-84.

Tipnis, R.S., Chatterton, B.D.E. and Ludvigsen, R. 1978. Ordovician conodont Biostratigraphy of the Southern District of Mackenzie, Canada. in Stelck, C.R. and Chatterton, B.D.E., eds, Western and Arctic Canadian Biostratigraphy. Geological Association of Canada Special Paper, 18: 3991.

Tolmacheva, T.J. 2001. Conodont biostratigraphy and diversity in the LowerMiddle Ordovician of Eastern Baltoscandia (St. Petersburgh region, Russia) and Kazakhstan. Comprehensive summary of doctoral dissertation, Department of Earth Sciences, Uppsala University: 1-40.

Toomey, D. and Nitecki, M. 1979. Organic buildups in the Lower Ordovician (Canadian) of Texas and Oklahoma. Fieldiana Geology 2: 1-181.

Vaccari, N.E. 1993. El género Annamitella Mansuy, 1920 (Trilobita, Leiostegiidae) en el Ordovícico de la Precordillera argentina. Ameghiniana, 30: 395-405.

Vaccari, N.E. 1995. Early Ordovician trilobite biogeography of Precordillera and Famatina, western Argentina: preliminary results. in Cooper J.D., M.L.Droser and S.C. Finney, eds, Ordovician Odyssey: Short papers for the Seventh International Symposium on the Ordovician System. The Pacific section Society for Sedimentary Geology (SEPM): 193-196. Fullerton.

Vaccari, N.E. 2001. Trilobites de la Formación San Juan (Ordovícico Inferior), Precordillera Argentina. Ameghiniana, 38: 331-347.

Vaccari, N.E. 2003. Trilobites de la Formación San Juan (Ordovícico Inferior), Precordillera Argentina: Pliomeridae Raymond, 1913. Ameghiniana, 40: 239-248

Waisfeld, B., Sánchez, T.M. and Carrera, M. 1999. Biodiversification patterns in the early Ordovician of Argentina. Palaios, 14:198-214.

Wang Xiafeng, Chen Xiaohong, Li Zhihong and Wang Chuanshang. 2003 The Huanghuachang Section, potential as Global Stratotype for the base of the Middle Ordovician Series. in G.L. Albanesi, M.S. Beresi and S.H. Peralta, eds, Ordovician from the Andes, Proceedings of the 9th International Symposium on the Ordovician System, San Juan, Argentina. Serie Correlación Geológica 17, INSUGEO, Tucumán: 153-159.

Wang Xiaofeng, Li Zhihong, Chen Xiaohong and Wang Chuanshang. 2003. The conodont succession from the proposed GSSP for the Middle Ordovician base at Huanghuachang Section, Yichang, China. in G.L. Albanesi, M.S. Beresi and S.H. Peralta, eds, Ordovician from the Andes, Proceedings of the 9th International Symposium on the Ordovician System, San Juan, Argentina. Serie Correlación Geológica 17, INSUGEO, Tucumán: 161-166.

Webby, B.D. 1998. Steps toward a global standard for Ordovician stratigraphy. Newsletter Stratigraphy, 36: 1-33

Webby, B.D., Cooper, R.A, Bergström, S.M. and Paris, F. 2004. Stratigraphic framework and time slices. in B.D. Webby, F. Paris, M.L. Droser 
and I. G. Percival, eds, The Great Ordovician Biodiversification Event. Columbia University Press. New York: 41-47.

Williams, S.H. and Stevens, R.K. 1988. Early Ordovician (Arenig) graptolites

Zhen, Y.Y., Percival, I.G. and Webby, B.D. 2003. Early Ordovician conodonts from western New South Wales, Australia. Records of the Australian Museum, 55(2): 169-220.

\footnotetext{
Addendum

At the time we received page proof for this contribution, a new report by Stouge et al., titled "Graphic correlation of high-palaeolatitude Lower-Middle Ordovician boundary successions..." appeared on the web site of the International Subcommission on Ordovician Stratigraphy (http://www.ordovician.cn, 12/31/2005). In their report, Stouge et al. recognize two very similar species within the critical boundary interval: Protoprioniodus cf. aranda and a younger Cooperignathus aranda. They regard the species whose FAD we propose to mark the base of the Middle Ordovician as $P$. cf. aranda. In our proposal, we have accepted the synonymy included in the revision of $C$. aranda by Zhen et al. (2003) because our collections from the Niquivil section lack the $\mathrm{P}$ elements of $C$. aranda s.s. Consequently, in our present report, we have combined as $C$. aranda the ranges of the two species recognized by Stouge et al. Even so, the Niquivil forms illustrated in Figure 8 (A3 and B1-5) can be correlated with precision as discussed in the text. As demonstrated graphically by Stouge et al. and Sweet and Albanesi (see Episodes, this number), the FAD of Protoprioniodus cf. aranda (sensu Stouge et al.) is near the isograptid radiation, a level preferred to mark the base of the Middle Ordovician. (Following this interpretation, the apparatus of $P$. cf. aranda includes elements $\mathrm{M}, \mathrm{Sc}, \mathrm{Sb}, \mathrm{Sa}$, and $\mathrm{P}$, which correspond to Figure 8 B15, respectively. Figure 8 A3 is element $\mathrm{P}$ of $P$. cf. aranda).
}

Guillermo L. Albanesi, CONICET researcher, Museum of Paleontology, National University of Córdoba, Argentina. Geologist, 1991, and Doctor, Geological Sciences, 1997, Nat. Univ. Córdoba, Argentina. Author or co-author of numerous papers and reports on conodonts and lower Paleozoic biostratigraphy. Editor of proceedings of the 9th International Symposium on the Ordovician System. Secretary of the ISOS, IUGS, since 1999. CONICET fellowship at Nat. Univ. Córdoba and La Rioja, Argentina, and Univ. Victoria, B.C., Canada. Fulbright-Antorchas fellowship at The Ohio State Univ., USA. Extensive field studies in western and north western Argentina. Current projects on conodont-graptolite biostratigraphy, paleoenvironments, bioevents, and paleothermometry from lower Paleozoic basins of South America.

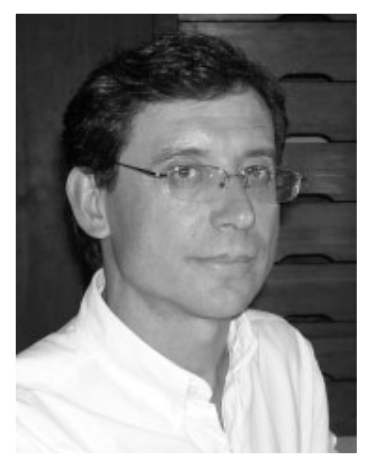

\title{
CALL FOR PAPERS
}

Episodes is the quarterly science and news journal of the International Union of Geological Sciences (IUGS). It focuses on the publication of results of scientific research and other information addressing issues of interest to the global earth-science community. Special emphasis is given to topics involving geological aspects of population growth and economic development and their resulting impacts on or implications for society. As the principal publication of the IUGS, Episodes also carries information about IUGS scientific programs and activities to the extent necessary to communicate effectively with the worldwide IUGS constituency.

Contributions of the following types of manuscripts are here solicited:

- review papers

- scientific articles

- conference reports

- news and views

- letters to editor

- book reviews

- information on training courses (especially those geared to participants from developing countries)

- noteworthy new publications, including national or regional geologic maps

Episodes also invites photos or other images for the front cover. Photos must be of high technical quality and tell an interesting geological story. A color transparency and one color print (at least $9 \mathrm{~cm} \times 12.6 \mathrm{~cm}$ ) are required for submission, which should be supplemented with a short explanatory paragraph (no more than 100 words).

Please address all contributions to:

\author{
The Editor \\ Episodes \\ P. O. Box 823, 26 Baiwanzhuang Road \\ 100037 Beijing, CHINA \\ Tel: +86-10-68320827, +86-10-68329084 \\ Fax: +86-10-68328928 \\ E-mail: episodes88@yahoo.com
}

